\title{
Mussel Community Composition in Relation to Macrohabitat, Water Quality, and Impoundments in the Neversink River, New York
}

By Barry P. Baldigo, George E. Schuler, and Karen Riva-Murray

U.S. GEOLOGICAL SURVEY

Open-File Report 02-104

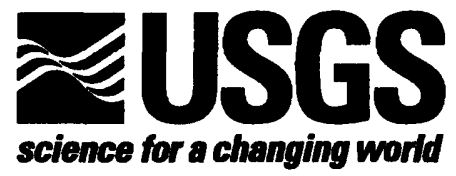

Troy, New York

2002 


\section{U.S. DEPARTMENT OF THE INTERIOR}

Gail A. Norton, Secretary

U.S. GEOLOGICAL SURVEY

Charles G. Groat, Director

The use of firm, trade, and brand names in this report is for identification purposes only and does not constitute endorsement by the U.S. Geological Survey.

For additional information write to:

District Chief

U.S. Geological Survey

425 Jordan Road

Troy, NY 12180
Copies of this report can be purchased from:

U.S. Geological Survey Branch of Information Services

Box 25286

Denver, CO 80225-0286 


\section{CONTENTS}

Abstract

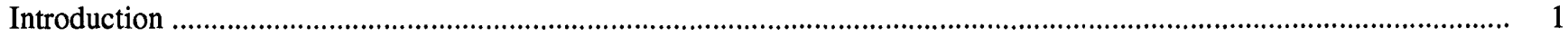

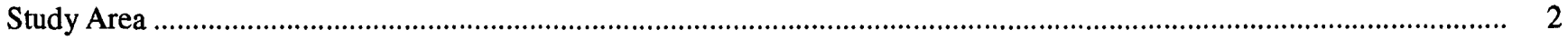

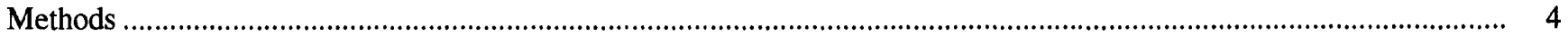

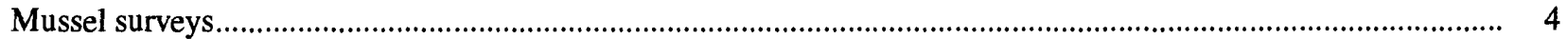

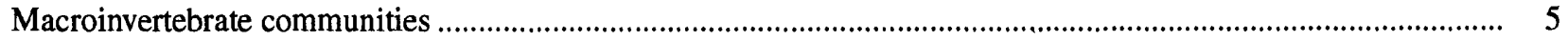

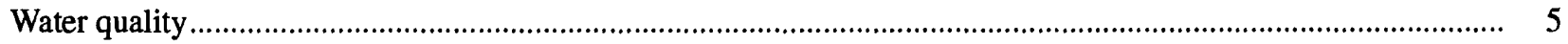

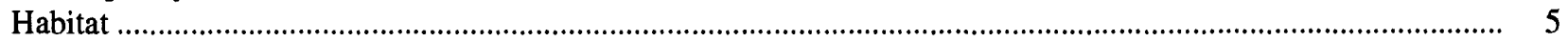

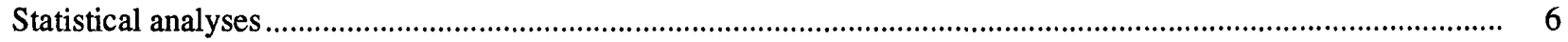

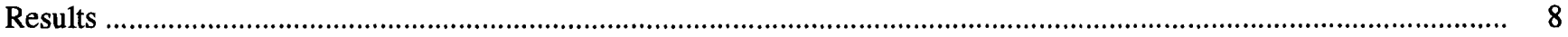

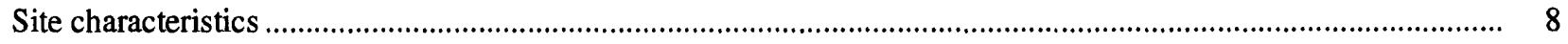

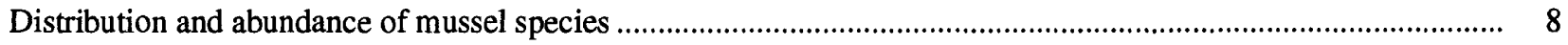

Abundance of macroinvertebrate species ..................................................................................................... 10

Correspondence analyses of macroinvertebrate species ................................................................................ 11

Canonical correspondence analyses of macroinvertebrate species....................................................................... 13

Canonical correspondence analyses of mussel species …………………………………….............................. 16

Correlation and regression analyses ............................................................................................................... 17

Differences in environmental variables among mussel-site groups....................................................................... 19

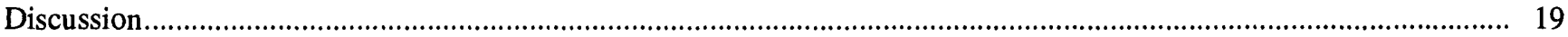

Mussel-community richness ................................................................................................................... 19

Abundance and distribution of Alasmidonta varicosa populations........................................................................... 21

Abundance and distribution of Alasmidonta heterodon populations.................................................................... 21

Long-term perspective for endangered Alasmidonta heterodon populations ........................................................... 22

Effects of the Cuddebackville and Neversink Dams on Alasmidonta heterodon populations ..................................... 22

Implications for management of natural resources in impounded rivers............................................................... 23

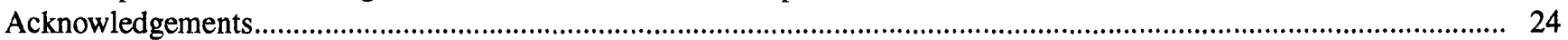

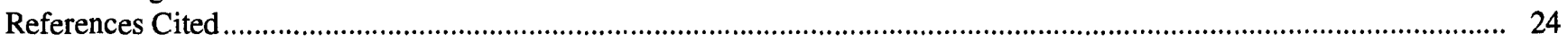

\section{Figures}

1. Locations of 28 sites studied June - August, 1997 in the Neversink River Basin in southeastern New York

2. Percent total (A) and catogorical-relative (B) abundance of mussel species collected during surveys of 20 stream reaches in the Neversink River Basin, N.Y., June-July, 1997.

3. Species richness, EPT (Ephemeroptera, Plecoptera, and Trichoptera) richness, Hilsenhoff Index of Biotic Integrity (HBI), and New York State Department of Environmental Conservation (DEC) thresholds for slight water quality impacts at 26 sites in the Neversink River Basin, N.Y., July 1997.

4. Unconstrained correspondance analysis (CA) ordination scatter plot of sites in the Neversink River, 1997, (A) based on a log-translated macroinvertebrate-species matrix at all 26 sites (nv01 is not shown but located at about -0.2 [ax1] and +0.75 [ax2]) and (B) based only on the 20 sites where habitat was characterized. Sites are catagorized as those with (1) no mussel species, (2) E. complanata and no more than 1 other 2 individuals of another species, (3) multiple mussel species but no A. heterodon, and (4) multiple mussel species and A. heterodon .....

5. Canonical correspondance analysis (CCA) biplot of final environmental variables in relation to 19 sites in the Neversink River Basin, 1997. Plotting positions of sites are based on log-transformed percentage macroinvertebratespecies data and are constrained by (A) spatially-structured environment and (B) pure environment (using spatial covariables). Sites are catagorized as those with (1) no mussel species, (2) E. complanata and no more than 1 other 2 individuals of another species, (3) multiple mussel species but no A. heterodon, and (4) multiple mussel species and $A$. heterodon 
6. Percent of variation in (A) mussel-community richness and relative abundance for (B) A. heterodon and (C) A. varicosa populations explained by environmental and spatial variables using partial multiple regression analyses; and the percent variation in (D) relative abundance of the mussel-species matrix and (E) percent abundance of the macroinvertebrate-species matrix explained by pure environment and pure space using partial canonical correspondence analyses at 19 to 20 sites in the Neversink River Basin, 1997. The percent of variation explained by overlap in environmental and spatial data, the Cuddebackville Dam, and which remain unexplained, are also estimated

7. Canonical correspondance analysis (CCA) biplot of final environmental variables in relation to 20 sites in the Neversink River Basin, 1997. Plotting positions of sites are based on similarily of mussel-species assembleges and constrained by (A) spatially-structured environment and (B) pure environment (using spatial covariables). Sites are catagorized as those with (1) no mussel species, (2) E. complanata and no more than 1 other 2 individuals of another species, (3) multiple mussel species but no A. heterodon, and (4) multiple mussel species and A. heterodon.....

8. Box and whisker plots showing the interrelations of select final environmental variables among Neversink River sites, (excluding nv01 and bk02) from the four mussel-site groups. Sites are catagorized as those with (1) no mussel species, (2) E. complanata and no more than 1 other 2 individuals of another species, (3) multiple mussel species but no $A$. heterodon, and (4) multiple mussel species and $A$. heterodon

Tables

1. Names and identification codes for the 28 sites sampled in the Neversink River Basin, 1997.

2. The 26 final environmental variables used in canonical correspondence analyses to assess the relations of environmental variables (water-quality, substrate, channel, bank, and landscape) to the distribution of mussel and macroinvertebrate species at 20 sites in the Neversink River Basin, 1997.

3. Selected chemical and physical data for 20 sites in the Neversink River Basin, N.Y., June-July 1997.

4. Summary of canonical correspondence analyses (CCA) showing the variance in (1) the log-transformed percentage macroinvertebrate species matrix at 19 sites (nv01 is excluded) and (2) the relative-abundance mussel species matrix at 20 sites explained by (A) spatially-structured environmental variables and either (B) pure space or (C) pure environment in the Neversink River Basin, 1997.

5. Canonical coefficients for standardized environmental and spatial variables and covariables, and for a binary variable depicting a site's relation to the Cuddebackville Dam, with the first four CCA axes that depict similarity of nonmussel macroinvertebrate (percent abundance) and mussel species (relative abundance) among 19 to 20 sites (nv01 is excluded for macroinvertebrate CCAs) in the Neversink River Basin, 1997.

6. Pearson coefficients of correlation $(R)$ for environmental and spatial variables with the number (richness) of mussel species, and with the relative abundance of $A$. varicosa and $A$. heterodon populations at up to 20 sites in the Neversink River Basin, 1997. Most correlations were significant $(p \leq 0.05)$ at $R>0.43$ using 19 dof ..... 


\title{
Mussel Community Composition in Relation to Macrohabitat, Water Quality, and Impoundments in the Neversink River, New York
}

\author{
By ${ }^{1}$ Barry P. Baldigo, ${ }^{2}$ George E. Schuler, and ${ }^{3}$ Karen Riva-Murray
}

\section{ABSTRACT}

Decreases in mussel-species richness and their distributions in rivers worldwide may indicate that these long-lived organisms could be adversely affected by recent changes in the suitability of habitat and quality of surface waters. Impoundments are considered major factors contributing to these declines in rivers of North American. Unionid mussels, other benthic macroinvertebrates, and local physiographic, habitat, and water-quality conditions were characterized across a partially regulated river in southeastern New York State during 1997 to evaluate factors that affect the distribution of two rare mussel species, Alasmidonta heterodon and Alasmidonta varicosa, and the richness of mussel communities. Results from multivariate analyses indicate: (1) macrohabitat features such as percent open canopy, mean channel width, mean bank width, several water-quality factors (e.g., conductivity and $\mathrm{pH}$ ), and site physiography (e.g., elevation and drainage area) were related to mussel-community richness and the distribution of $A$. heterodon populations; and (2) the abandoned, low-head Cuddebackville Dam may

\footnotetext{
${ }^{1}$ Barry P. Baldigo, U.S. Geological Survey, 425 Jordan Road, Troy, NY 12180

${ }^{2}$ George E. Schuler, The Nature Conservancy, Neversink Preserve, P.O. Box 617, Cuddebackville, NY 12729

${ }^{3}$ Karen Riva-Murray, U.S. Geological Survey, 425 Jordan Road, Troy, NY 12180
}

have restricted $A$. heterodon populations to the lower reaches of the system. Impoundments may have had both positive and adverse affects on mussel populations in the Neversink River, thus, the full effects of impoundments on biodiversity of aquatic ecosystems need to be well understood for effective management of water and biological resources in rivers of the world.

\section{INTRODUCTION}

Freshwater mussels (Unionidae) are some of the most imperiled fauna in North America - from 43 to $72 \%$ of the native species have been classified as extinct, endangered, threatened, or vulnerable (Master 1990, Bogan 1993, Williams and others. 1993; Williams and Neves 1995). Decreases in musselspecies richness and their distributions in rivers worldwide indicate that these long-lived organisms could be adversely affected by recent changes in the suitability of habitat and quality of surface waters. Although impoundments and associated changes in water quality, resident fish populations, and temperature and flow and sediment regimes contribute to these declines (Brim-Box and Mossa 1999; Williams and Neves 1995; Vaughn and Taylor 1999), specific factors and processes that affect the abundance of mussel populations and the distribution of mussel species are poorly understood (Strayer 1983, Strayer and Ralley 1993). A few investigations have found or proposed that certain microhabitat conditions can restrict mussel species to isolated patches in river beds. For example, Strayer and Ralley (1993). Others (Layzer and Madison 1995, Strayer 1993, Strayer and Ralley 1991) determined that shear 
stress, water velocity, substrate particle sizes, and sediment stability might affect the presence or absence of certain species and richness of mussel species in riverine systems. Little is known, however, about specific macrohabitat factors that limit populations of rare mussel species to particular reaches of a given river. In this report, "microhabitat" refers to environmental factors that potentially affect mussel species at the location of an individual specimen and are generally on a scale of a meter or less, whereas "macrohabitat" refers to chemical and physical factors that potentially affect species populations at a scale of 100 's of meters (reach level) and may include physiographic factors measured at the landscape or watershed level, such as elevation, runoff, discharge, and drainage area. General macrohabitat features appear to determine the suitability of a river reach for certain mussel species; and correlated or unrelated microhabitat factors limit where stable mussel beds (patches) can become established within suitable reaches. Thus, complex interactions of mussels with host-fish species and micro- and macro-habitat features likely affect the distribution of mussel species in a given system.

The Neversink River in southeastern New York State (Fig. 1) possesses the richest diversity of freshwater mussels in the upper Delaware River Basin (Strayer and Ralley 1991). One of the seven mussel species that occur in the Neversink was federally endangered, and another was on the draft New York State threatened-species list (The Nature Conservancy 1999). Populations of endangered dwarf wedgemussels (Alasmidonta heterodon) appear to be restricted to a 12- to $18-\mathrm{km}$ section in the lower third of the basin, whereas the threatened swollen wedgemussels (Alasmidonta varicosa) occupy in the lower half of the basin (Strayer and Ralley 1991, Strayer and others, 1996). Dwarf wedgemussels have been collected only in the lower Neversink River below an abandoned lowhead dam near Cuddebackville (Fig. 1) (Strayer and Ralley 1991, The Nature Conservancy 1999). The limited distribution of $A$. heterodon suggests that they may be susceptible to local extinctions that could result from catastrophic floods, localized fuel or chemical spills, or an epidemic disease. Protecting and promoting $A$. heterodon in the Neversink is problematic, however, because (1) they occur in patchily distributed beds which make distributions difficult to quantify, (2) the abandoned Cuddebackville Dam may restrict upstream movement of their host fish and $A$. heterodon distributions, and (3) the relationship of environmental factors to the distribution and abundance of their populations are poorly defined (Strayer and others 1996, Strayer 1993, Strayer and Ralley 1993, The Nature Conservancy 1995).

A spatial survey of water quality, physical habitat, hydrology, mussel populations, and macroinvertebrate communities of the Neversink River Basin was conducted during 1997 to (1) document the distribution of the two rare mussel species, (2) relate observed patterns in mussel-species richness and the distributions of rare mussel species to environmental factors, and (3) evaluate the potential effect of the lowhead Cuddebackville Dam on the distribution of dwarf wedgemussels in the basin.

\section{STUDY AREA}

The Neversink River drains an area of about 1126 $\mathrm{km}^{2}$ and is part of the $34,000 \mathrm{~km}^{2}$ Delaware River Basin. The Neversink flows through four distinct physiographic regions. The $238 \mathrm{~km}^{2}$ upper Neversink sub-basin is mountainous and terminates at the Neversink Reservoir and Dam. The $606 \mathrm{~km}^{2}$ middle Neversink, located between the reservoir and the confluence with the Basha kill, starts as a broad floodplain but passes through a narrow gorge for most of its length. The $93 \mathrm{~km}^{2}$ lower Neversink watershed is broad river with an ancient, wide floodplain. The 189 $\mathrm{km}^{2}$ Basha Kill sub-basin is the largest tributary to the lower Neversink and consists of a $12 \mathrm{~km}^{2}$ stillwater marsh and several small tributaries.

The Neversink watershed is relatively undeveloped with only two medium-sized cities, Monticello and Port Jervis, and several small villages in the basin. The upper Neversink watershed is sparsely populated and contains mixed forests of hardwood hemlock, and spruce. The stream channels are generally formed in bedrock. Waters from the upper basin drain into the Neversink Reservoir, which was created in 1953 by the Neversink Dam, for public (City of New York) water-supply purposes. Below the reservoir, the river flows over an unconfined sand and gravel aquifer for much of its length. The alluvial aquifer is relatively narrow and confined in the upper reaches of the watershed and becomes a broad gravel floodplain downstream from the Neversink River's confluence with the Basha Kill. Below this confluence, the water table is close to the surface, and produces several spring-fed creeks and small marshes. The middle and lower reaches of the Neversink River are about 30 to $40 \mathrm{~m}$ wide and 0.3 to 1.2 deep during the 
CONVERSION FACTORS, ABBREVIATIONS AND VERTICAL DATUM

\begin{tabular}{rccl}
\hline Multiply & & By & \multicolumn{1}{c}{ To Obtain } \\
\hline & Length & millimeter \\
inch (in) & 25.40 & meter \\
foot (ft) & 0.3048 & kilometer \\
& 1.609 & \\
sile (mi) & Area & square kilometer \\
& 2.59 & \\
million gallons per day (Mgal/d) & Flow & cubic meters per second \\
& 0.0438 & \\
& Hydraulic conductivity & \\
foot per day (ft/d) & 0.3048 & meter per day \\
& Other abbreviations used in this report \\
micrograms per liter $(\mu \mathrm{g} / \mathrm{l})$ & \\
milligrams per liter $(\mathrm{mg} / \mathrm{L})$ & \\
millisiemens per meter $(\mathrm{mS} / \mathrm{m})$ &
\end{tabular}

Sea level: In this report, "sea level" refers to the National Geodetic Vertical Datum of 1929 (NGVD of 1929)--a geodetic datum derived from a general adjustment of the first-order level nets of the United States and Canada, formerly called Sea Level Datum of 1929. 


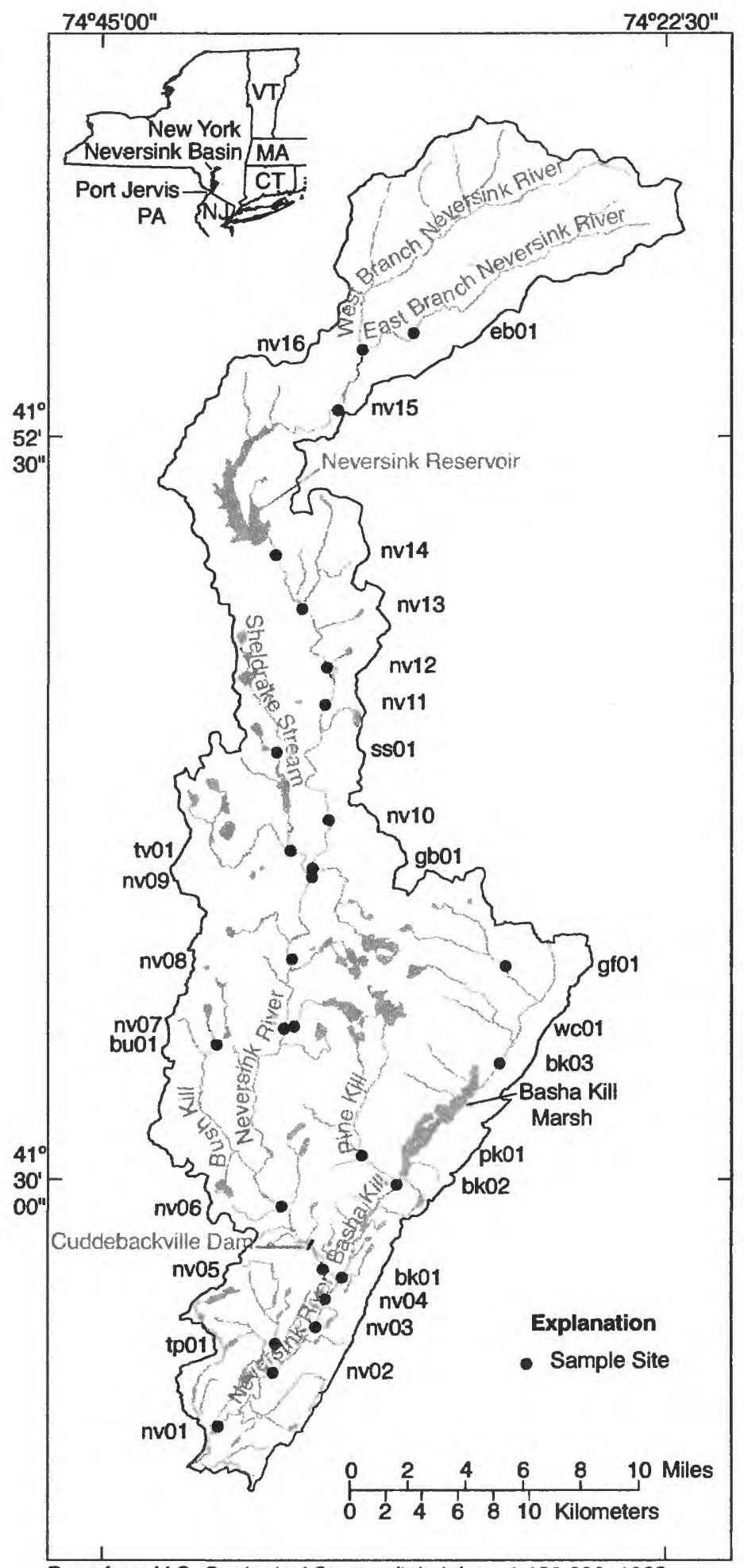

Base from U.S. Geological Survey digital data, 1:100,000, 1983 Universal Transverse Mercator Projection, Zone 18

Figure 1. Locations of 28 sites studied June - August, 1997 in the Neversink River Basin in southeastern New York.

(Site names are listed in Table 1.) summer months, however, pools deeper than $5 \mathrm{~m}$ are not uncommon in the gorge. The bottom substrate is typically dominated by cobble, rocks and boulders, with sand and gravel interspersed. Waters of the main-stem Neversink are generally clear and fairly soft, with calcium levels less than $200 \mu \mathrm{mol} / \mathrm{L}$.

Both the Neversink Dam and the abandoned Cuddebackville Dam have the potential to affect hydrology, sedimentation, and assemblages of aquatic species in the basin. The Neversink Reservoir covers $6.1 \mathrm{~km}^{2}$ in surface area and impounds $132,500,000 \mathrm{~m}^{2}$ of water. Total annual discharge, the magnitude of flows from annual snowmelt, spring and fall storm events, and the duration of high and low flow pulses and the total flows in the middle and lower reaches of the Neversink Basin have been severely altered by the Neversink Dam. During a 12-month period that approximated the 1997 water-year, the reservoir released an average of 1.1 cubic meters of water per second (cms) into the Neversink River (average daily flows varied from 0.7 to $2.0 \mathrm{cms}$ depending on season) immediately downstream, with an additional $6.2 \mathrm{cms}$ diverted continuously to the New York City water-supply system (Butch and others, 1998; Krejmas and others, 1998). The total annual diversion is roughly $85 \%$ of the river's natural flow as determined at a USGS gage located about $0.5 \mathrm{~km}$ below the reservoir. The annual mean discharge before and after impoundment at several USGS gages in the middle basin fell from $7.5 \mathrm{~m}^{3} / \mathrm{s}$ to just over $1.4 \mathrm{~m}^{3} / \mathrm{s}$, the average length of low-flow pulses increased from 6 to 44 days, and the average length of high-flow pulses dropped from 5.3 to 2.7 days (The Nature Conservancy 1999). Further downstream, the effects of the reservoir on flow are attenuated by the increased drainage area of the lower Neversink watershed. The water released into the Neversink River below the dam accounts for only about $8 \%$ of the total discharge at a USGS gage located 55 $\mathrm{km}$ downstream from the reservoir (Butch and others, 1998). Mean annual flows at this gage decreased from nearly $17.3 \mathrm{~m}^{3} / \mathrm{s}$ to $12.0 \mathrm{~m}^{3} / \mathrm{s}$ after impoundment, a decline of roughly $30 \%$. As a large impoundment, the Neversink Reservoir has lowered flood potential, disrupted the natural hydrologic-flow regimes, and altered sediment transport in the middle and lower parts of the basin. The impassible barrier also changes the 
thermal and chemical quality of outflow waters, which should affect fish migration and aquatic ecosystems in parts of the middle basin.

The Cuddebackville Dam, because of its small size and low-head, has probably had limited affects on biological communities of the river system. This dam was located on the mainstem Neversink River about $2.5 \mathrm{~km}$ upstream from its confluence with the Basha Kill. It was first constructed in the early 1800 s as a diversion structure to supply water for the Delaware and Hudson Canal, abandoned in 1899, then rebuilt and abandoned again in the middle 1900s. It currently is in disrepair, has a 2 to $3 \mathrm{~m}$ waterfall which holds back a relatively small amount of sediment and water, and blocks upstream movement of resident as well as anadromous fish species. Though historic fishery data are unavailable, the Cuddebackville Dam could have eliminated diadromous fish species in the lower and middle reaches of the basin.

TABLE 1. Name, station number, and site code for the 28 sites sampled in the Neversink River Basin, 1997.

[Locations are shown in Fig. 1.]

\begin{tabular}{lc}
\hline \multicolumn{1}{c}{ Site name } & Site code \\
\hline Basha Kill below marsh, Cuddebackville, 01437400 & bk01 \\
Basha Kill at marsh, Cuddebackville, 01437370 & bk02 \\
Basha Kill upstream of marsh, Wurtsboro, 01437316 & bk03 \\
Upper Bush Kill, Oakland Valley, 01436791 & bu01 \\
East Branch Neversink River at Claryville, 01434017 & eb01 \\
Fowlwood Brook at Bridgeville, 0143658105 & gb01 \\
Gumar Falls Brook at Wurtsboro, 01437080 & gf01 \\
Neversink River at Port Jervis, 01437744 & nv01 \\
Neversink River at Huguenot, 0143770004 & nv02 \\
Neversink River at TNC preserve, Godeffroy, 01437514 & nv03 \\
Neversink River at Graham Road bridge, Godeffroy, 01437500 & nv04 \\
Neversink River at Cuddebackville, 01437025 & nv05 \\
Neversink River near Hartwood, 01437010 & nv06 \\
Neversink River gorge at Wolf Creek, Monticello, 01436749 & nv07 \\
Neversink River gorge at Monticello, 01436725 & nv08 \\
Neversink River at Bridgeville, 01436661 & nv09 \\
Neversink River at South Fallsburg, 01436559 & nv10 \\
Neversink River at Fallsburg, 01436511 & nv11 \\
Neversink River at Woodbourne, 01436500 & nv12 \\
Neversink River. at Hasbrook, 01436450 & nv13 \\
Neversink River below Neversink Dam, Neversink, 01436000 & nv14 \\
Neversink River at Claryville, 01435000 & nv15 \\
West Branch Neversink River at Claryville, 01434498 & nv16 \\
Pine Kill at Wurtsboro, 01437351 & pk01 \\
Sheldrake Stream near Fallsburg, 0143660102 & ss01 \\
Unnamed Tributary at Huguenot, 01437672 & tp01 \\
Sheldrake Stream at Thompsonville, 01436655 & tv01 \\
Wolf Creek near Monticello, 01436752 & wc01 \\
\hline
\end{tabular}

\section{METHODS}

Twenty-eight sites on the mainstem and tributaries of the Neversink River were selected for sampling. Site locations and identifier codes (IDs) are shown in Fig. 1; site names are listed Table 1. Mussel searches were conducted during June 1997 at 24 sites (out of 28) from which previous mussel data were not available. Mussel data for 3 additional sites were obtained from semiquantitative surveys done between 1994 and 1997 (written communication, D. L. Strayer, Feb., 1998). Water-quality and macroinvertebrate samples were collected from 26 of the 28 sites (wc01 and bk03 were excluded), and habitat and hydraulic characteristics were measured at 20 of these 26 sites (eb01, gf01, gb01, pc01, and tp01 were excluded) during June-July 1997, when discharge was relatively stable and near base flow. Channel morphology, substrate-particle size, bank stability, riparian vegetation, and hydraulic characteristics were selected that (1) describe stream habitat at reach and pool/riffle scales (Frissell and others, 1986), and (2) have been hypothesized to affect mussel-community richness and mussel populations (Layzer and Madison 1995, Michaelson and Neves 1995, Strayer and others, 1996, Strayer 1993, Strayer and Ralley 1993).

\section{Mussel Surveys}

Timed-mussel searches were done in 100- to 400-meter long reaches at each of 24 sites. Two people searched for mussels at each site for a total of 1 hour by a combination of snorkeling and (or) wading with a view tube. Searches were extended to 2 hours if mussels were found during the first hour of effort. Once a mussel bed was located, it was searched intensively, and all individuals found were identified, counted, and returned to the bed. Though longer searches were not feasible for the present study, a recent investigation of sampling efficiencies for timed mussel searches (Metcalfe-Smith and others, 2000) showed that more rare species might be found if search times were at least 4.5 person hours per site. 


\section{Macroinvertebrate Communities}

Nonmussel macroinvertebrate-species assemblages were used as a surrogate for mussel communities during initial multivariate analyses to identify gradients in environmental factors that might affect both communities. Benthic-macroinvertebrate samples were collected from riffles or runs by the traveling kick method with a $800 \times 900 \mathrm{~mm}$ mesh dip net, through the technique established by New York State Department of Environmental Conservation (NYSDEC) for stream biomonitoring (Bode and others, 1996). Samples were rinsed in a 200-mm mesh sieve and preserved in $95 \%$ ethanol. At the laboratory, 200 specimens were randomly selected from each sample, identified to the lowest possible taxonomic level (generally species or genus), and enumerated. Original percentage data $(\mathrm{x})$ were transformed to $\mathrm{x}$ ' by $\ln (x+1)$ to (1) normalize skewed macroinvertebratespecies distributions and (2) permit percentages below 1.0 to be transformed to positive integers and used in CANOCO analyses (ter Braak and Smilauer 1998).

\section{Water Quality}

Stream temperature, $\mathrm{pH}$, conductivity, and concentration of dissolved oxygen (DO) were measured with field meters. A grab sample was collected from a well-mixed section of midchannel, placed on ice, and transported to the U.S. Geological Survey (USGS) Laboratory in Troy, NY. Water samples were analyzed for $\mathrm{pH}$, conductivity, acidneutralizing capacity (ANC), dissolved organic carbon (DOC), nitrate $\left(\mathrm{NO}_{3}\right)$, sulfate $\left(\mathrm{SO}_{4}\right)$, silica $(\mathrm{Si})$, total dissolved aluminum $\left(\mathrm{Al}_{\mathrm{td}}\right)$, total monomeric aluminum $\left(\mathrm{Al}_{\mathrm{tm}}\right)$, organic monomeric aluminum $\left(\mathrm{Al}_{\mathrm{om}}\right)$, inorganic monomeric aluminum $\left(\mathrm{Al}_{\mathrm{im}}\right)$, calcium (Ca), magnesium $(\mathrm{Mg})$, and potassium $(\mathrm{K})$ in accordance with methods described in Lawrence and others, (1995).

\section{Habitat}

At each site, habitat-survey reaches were established that bounded local mussel beds and search areas. These reaches were generally 20 mean stream widths (MSW) in length (Meador and others, 1993, Simonson and others, 1993, Simonson and others, 1994), but no longer than a predetermined $300-\mathrm{m}$ maximum. The length of each geomorphic channel unit (pool, riffle, run) in each reach was measured according to methods summarized in Meador and others, (1993). In-stream channel features and bank conditions were measured or characterized at 5 to 7 transects spaced 1 to $2 \mathrm{MSW}$ apart, depending on stream width. Transect spacing varied according to stream width to provide a roughly uniform sample size among streams, regardless of width (Simonson and others, 1994). Transect spacing was $1 \mathrm{MSW}$ in streams $\geq 10 \mathrm{~m}$ wide and $2 \mathrm{MSW}$ in streams less than $10 \mathrm{~m}$ wide. Angle of open canopy was estimated with a climometer at the midpoint of each transect (Meador and others, 1993). Bankfull width and height and wetted width were measured for each transect (Simonson and others, 1994). Indicators of recurring high flows, such as debris dams, erosion lines, and vegetated extent were used to estimate bankfull width and height.

Measurements of channel depth and substrate types, water velocity, and estimates of percent algal and macrophyte cover, were made at 5 or 7 equally spaced points across the transect and at the thalweg. Measurements were generally made at 5 points in channels $\leq 20 \mathrm{~m}$ wide, and at 7 points in channels $>20$ $\mathrm{m}$ wide. Water depth was measured to the nearest $\mathrm{cm}$, velocity was measured at six-tenths depth with a mechanical or electromagnetic water-velocity meter, and depth of fine sediments was measured according to methods described in Simonson and others, (1994). Substrate sizes for the reach were quantified by modified Wolman-count methods (Wolman 1954), in which 5 particles were randomly selected in the vicinity of each transect point, and the intermediate particle lengths recorded. Embeddedness was estimated to the nearest 5\% (Platts and others, 1983) for 3 gravel or larger-sized particles at each point. Fluctuations in discharge, stage, and related variables were relatively small during the sampling period.

Bank and riparian characteristics, unless otherwise noted, were measured or visually estimated at each transect according to methods described in Meador and others, (1993). The stream bank was defined as beginning at the edge of water. Bank shape was characterized as linear, concave, or convex. The percent of vegetated bank (bank cover), angle of inclination, substrate type, and degree of erosion were estimated at both ends of each transect. Various landuses classes, and the percentage of each on both banks were determined from edge of water to $10 \mathrm{~m}$ away from the bank at all transects through methods of Simonson and others, (1994). Percentages of each land use class from the stream bank to $50 \mathrm{~m}$ away from the bank were visually estimated at both ends of each transect. 
Discharge at each site was calculated as the average of flows determined for each transect; transect flows were determined from point velocities, depths, and widths of all transect segments by standard USGS methods (Rantz 1983). Elevation, stream-channel gradient, and watershed drainage area of each reach were determined from 1:24,000 scale USGS maps.

\section{Statistical Analyses}

Four data sets were created and assessed to identify the relations between the environment, 2dimensional location (space), and mussel and nonmussel (macroinvertebrate) communities at 20 sites where habitat was characterized. The data sets were (1) environmental data (single values or statistics for mean, median, minimum, and maximum values, as applicable) describing water-quality, physiographic, and habitat characteristics, (2) spatial coordinates for latitude and longitude and a binary variable for each site's upstream or downstream orientation to the Cuddebackville Dam, (3) relative abundance of mussel species, and (4) percent abundance of macroinvertebrate taxa at each site. Data sets summarize measures for dependent variables by sample (site) rows and biotic species or physical variable (species, space, or environment) columns and, therefore, can be described as species, spatial, or environmental matrices.

Unconstrained correspondence analyses (CA), and constrained canonical correspondence analyses (CCA) (ter Braak and Smilauer 1998) and multiple regression analyses were used to assess the relations of environmental and spatial variables to the dispersion of macroinvertebrate and mussel species among the study sites. The variation in mussel and macroinvertebrate species data explained by environmental variables assumes that the sites were spatially independent. Because study sites in the basin were nested, however, conditions at one site may influence environmental characteristics and mussel and macroinvertebrate species at adjacent sites, especially those downstream. To account for spatial dependency among macroinvertebrate, mussel, and environmental variables, we included spatial location of sampling sites in our analyses (Legendre and Legendre 1998). Both partial CCA (PCCA) (Borcard and others, 1992; ter Braak and Smilauer 1998) and partial multiple regression analyses (PMRA) (Legendre and Legendre 1998) were used to partition the variation in mussel and macroinvertebrate species matrices explained by (a) pure environment, (b) pure space, and (c) overlap in environment and space and (d) the percent of the variation that was unexplained by measured variables. Though spatial analyses can produce misleading results in analyses of patterns in biological communities in mostly linear systems, it provides one way to estimate the effects of non-measured parameters and space on assemblages of interest.

Spatial data included (1) a binary variable -0 or 1 - for each site's position upstream or downstream from the Cuddebackville Dam and (2) each site's latitude and longitude. The binary data was only used to assess the effect of the dam on mussel and macroinvertebrate species distributions. Fractional (Cartesian) latitude and longitude coordinates ( $\mathrm{x}$ and y) were assessed through indirect gradient or correspondence analysis (CA) to generate standardized (about zero) site scores, which are linear combinations of latitude and longitude. By rotating the first, and only, two CA axes (ax1 and ax2), the sample (site) scores become standardized transformations of the original latitude and longitude data. The transformed coordinates ( $x$ and $y$ ) and their $3^{\text {rd }}$-order polynomial functions ( $x y, x^{2}, y^{2}, x^{2} y, y^{2} x, x^{3}$, and $y^{3}$ ) were used, along the binary dam variable, as spatial variables in all partial CCAs.

Computational needs for CCAs require that the large number of environmental variables be decreased to a manageable and interpretable list (ter Braak and Smilauer 1998). The number of independent variables must be one less than the number of samples (sites) to avoid over fitting patterns in response variables from small datasets with a large number of predictor variables (ter Braak and Smilauer 1998). The number of variables assessed was decreased in several steps. First, the distributions of all 99 original environmental variables, compiled and derived from field measures, were transformed by $\ln (\mathrm{y})$ or $\ln (\mathrm{y})+1$ to reduce skewed distributions and eliminate negative logtransformed values when original data were between 0 and 1.0. Forty-eight variables that contained mostly zero data, or that were strongly correlated with other variables were removed. From the remaining 51 environmental variables, 19 were chosen through Monte Carlo permutation tests and a forward selection process during a CCA of environmental and macroinvertebrate species data (ter Braak and Smilauer 1998). Environmental (and spatial) variables were retained that significantly $(p<0.10)$ explained the largest amount of variation remaining after selection of other variables in site and macroinvertebrate-species matrixes. An additional 7 
variables, which were strongly associated with the first 4 axes in a CA of the 51 environmental variables, were also included in the final data set. Thus, from the 99 original environmental variables, 26 final variables were selected for various analyses. Those variables determined by subsequent analyses to have significant effects on macroinvertebrate communities or musselspecies populations are termed key environmental variables. The final 26 water-quality, substrate, channel, bank, and landscape variables used in all CCAs are listed in Table 2.

Monte Carlo permutation tests were again used in forward selection of the final 26 variables (ter Braak and Smilauer 1998) to identify key variables that explained the most variation in percent abundance of the macroinvertebrate-species matrix and relative abundance of the mussel-species matrix. These analyses do not account for spatial dependency or autocorrelation among variables. The amount (percentage) of variation explained by environmental variables, therefore, was not pure; it includes some unknown amount of overlap related to spatial effects. An analogous CCA of species data using spatial variables quantifies the amount of variation due to spatial orientation, but the explained variation also includes overlap due to environmental effects. Using only the significantly related spatial variables $(p \leq 0.05)$ as covariables in a CCA of species with environmental variables removes spatial effects and quantifies the variation explained by pure environment. An analogous CCA with spatial variables and environmental covariables quantifies the variation explained by pure space. The percent variation in species data explained by (a) pure environment, (b) pure space, and (c) overlap between space and environment, and which was (d) undefined, can be partitioned by simple addition and subtraction of the four components (Borchard and others, 1992). Spatial and environmental variables used in PCCAs were restricted to those first identified by forward selection in original CCAs. Supplemental CCAs were done whereby forward selection, using significant spatial covariables, tested and incorporated several environmental variables that were not in the final group of 26; these results, however, were not interpreted by PCCAs.

The cumulative variance and proportion (percent). of variance in the species matrix explained by the first 4 canonical axes (quantified by eigenvalues for each axis) and total inertia (the sum of eigenvalues for all axes) were assessed to determine how well each axis described variation in respective species' matrices. Student $t$-values for canonical coefficients of independent variables on each axis that were greater than 2.1 indicate that the variable contributed beyond that of all other variables to the fit of the species data in the analysis (ter Braak and Smilauer 1998). CA and CCA ordination biplots were generated to graphically

TABLE 2. The 26 final environmental variables used in canonical correspondence analyses to assess the relations of environmental variables (water-quality, substrate, channel, bank, and landscape) to the distribution of mussel and macroinvertebrate species at 20 sites in the Neversink River Basin, 1997.

[Variables with asterisks were log-transformed.]

\section{Final environmental variables}

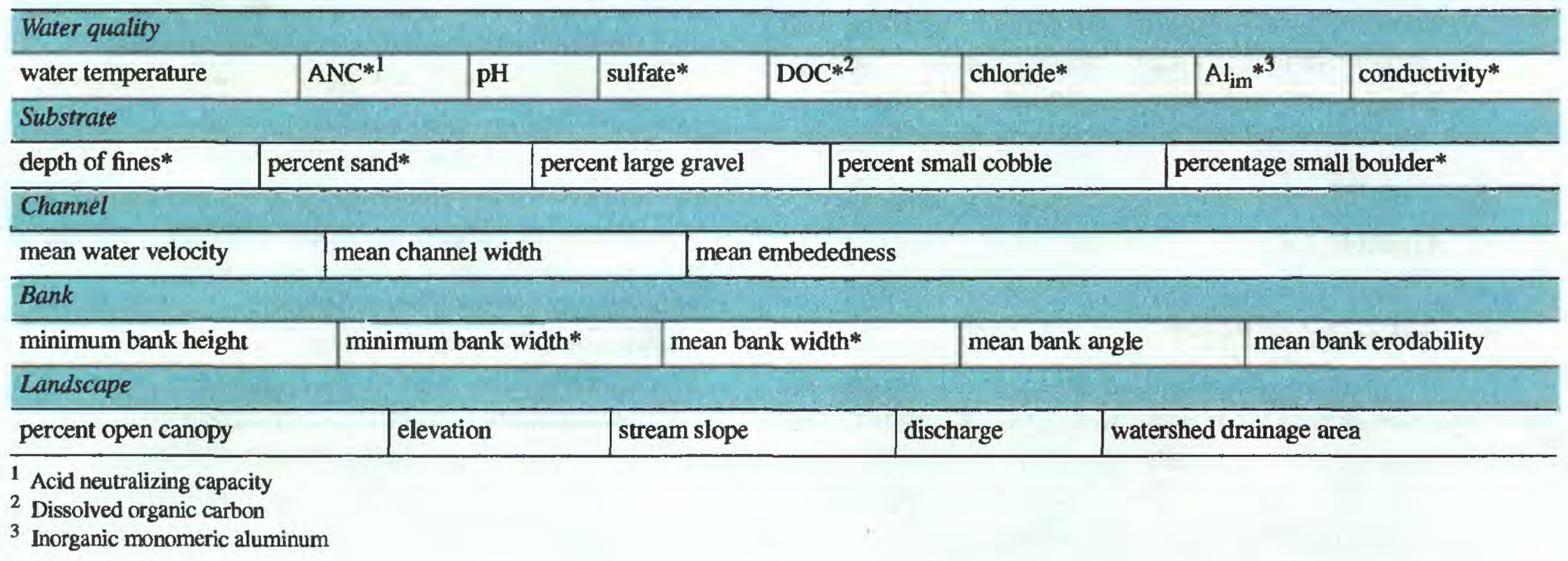


assess mussel-site groupings (groups or classes) and to show how key environmental variables were related to the dispersion of samples (sites) and species along the first two axes. If certain environmental factors were assumed to affect macroinvertebrate and mussel species (and communities) in a similar manner, then these key variables (or other variables strongly related to key variables) that account for the dispersion of samples (sites) in the macroinvertebrate CCAs should also be important to the distribution of rare and common mussel species in the basin. Key variables that explain the variation among sites and in macroinvertebrate- and mussel-species matrices (CCAs) were hypothesized to affect the distribution of rare and common mussel species. The key variables were subsequently evaluated through the nonparametric chi-square approximation of the Kruskal-Wallis test to determine whether the magnitude of key variables differed among sites from four mussel-site groups.

Spearman Rank correlations were used to approximate how strongly the original 51 environmental and 10 spatial variables were associated with the key environmental variables that explained most of the variation in macroinvertebrate- and mussel-species matrices. Most of the correlated factors could not be assessed directly in CCAs because of multicorrelation, but they may also contribute to the variation in species matrices attributed to the key environmental factors.

The strength of the relations among the original 51 environmental variables, the 10 spatial variables, and mussel-species richness, and the relative abundance of $A$. heterodon and $A$. varicosa species populations were also assessed through partial multiple regression analyses (PMRA) (Legendre and Legendre 1998). Although the procedures for PMRA and PCCA differ slightly, the percent variation attributed to environment, spatial structure, overlap of environment and space, and undetermined factors were quantified in a comparable manner.

\section{RESULTS}

\section{Site Characteristics}

Stream-site elevation, drainage area, slope, and other selected characteristics for the 20 study reaches (Table 3), with several exceptions, reflected typical differences between low-order, high-elevation sites with a small drainage area, steep slope, high velocities, and cool temperatures, and high-order, low-elevation sites with a large drainage area, low slope, low velocities, and warm temperatures. Several tributary sites of low to middle order, such as bu01, bk01, and bk02 (Fig. 1) originated in marshes and, thus, did not reflect typical lotic conditions. Sites nv13 and nv14, immediately below the Neversink Reservoir, and the lowest main-stem site, nv01 (Fig. 1), also exhibited unique physical conditions that resulted from their unusual flow, sediment, or thermal regimes. Most environmental data from these sites were unique and sometimes excluded from multivariate analyses.

Water-quality conditions ranged widely across the basin (Table 3). Three sites (nv16, nv15, and eb01) in the upper basin, and sites nv10, nv11, nv12, and nv14, below the Neversink Reservoir, showed some degree of acidification. High water temperatures (near $25^{\circ} \mathrm{C}$ ) and low concentrations of dissolved oxygen (DO) at sites bk02 and nv01 may have been unsuitable for certain benthic invertebrate species. The low DO concentration ( $4.5 \mathrm{mg} / \mathrm{L}$ ) of a single sample from bk02, just below the Basha Kill Marsh, was not limiting in itself but implied that marsh-like conditions at or upstream from both sites could have produced levels of DO near zero under warmer and (or) nighttime conditions and thus possibly be unsuitable for certain species. Low DO concentrations, combined with low stream slope and water velocities and a deep layer of fine sediments at nv01, may have also produced conditions unsuitable for typical riverine invertebrate species.

\section{Distribution and Abundance of Mussel Species}

Estimates of abundance for the seven unionid mussel species at 20 sites are shown as a percentage of the total number of individuals collected at each site in Fig. 2A, and, as a categorical or relative abundance in Fig. 2B. The relative-abundance values for each species ranged from 0 to 5 and correspond to numbers observed during visual searches: $0=$ absent, $1=$ rare, $2=$ low, $3=$ moderate, $4=$ common, and 5 very common. Elliptio complanata was the most widely distributed mussel species (Fig. 2) and, thus, may be very tolerant of the environmental conditions that occurred across the basin. Alasmidonta heterodon and Alasmidonta implicata were the most narrowly distributed species (except for Pyganodon cataracta) and, thus, may be intolerant of environmental conditions in parts of the basin. One Pyganodon cataracta specimen was collected at a stream site (ss01) that fed an abandoned beaver pond and was not 


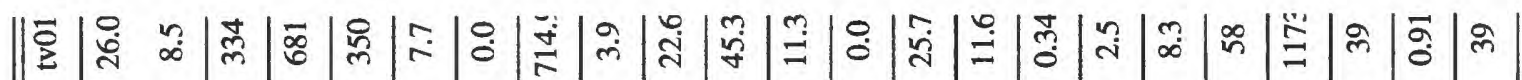

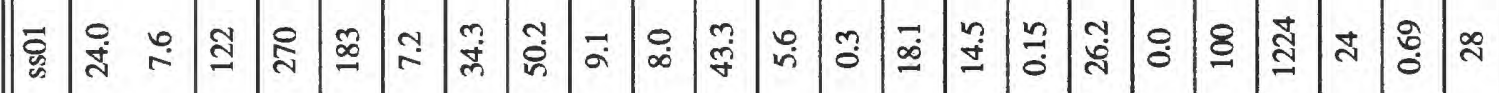

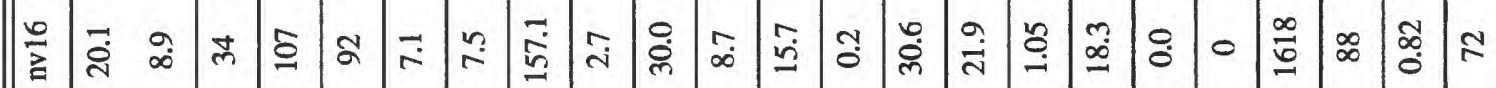

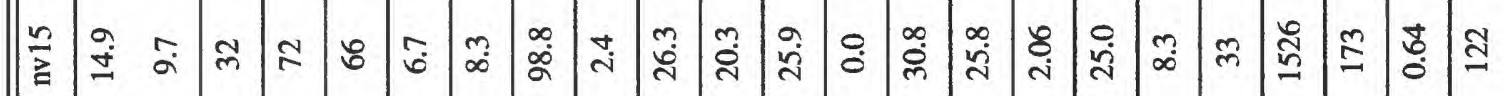

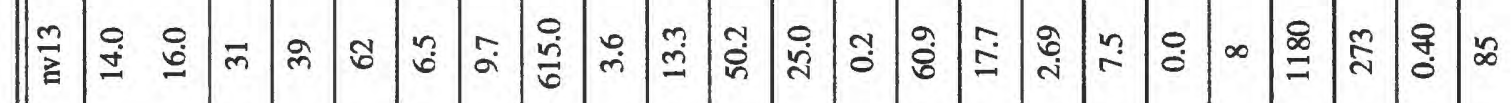

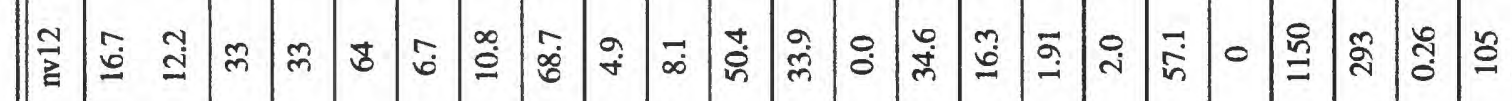

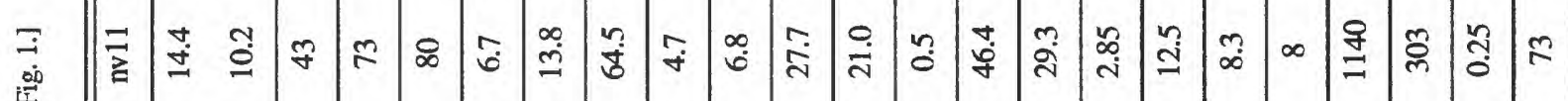

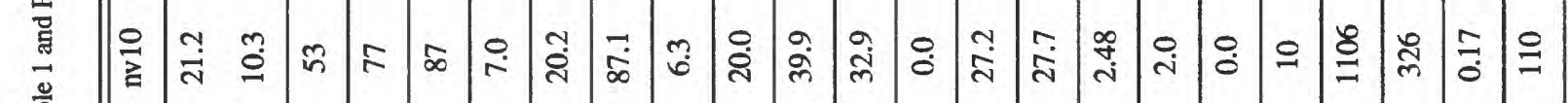

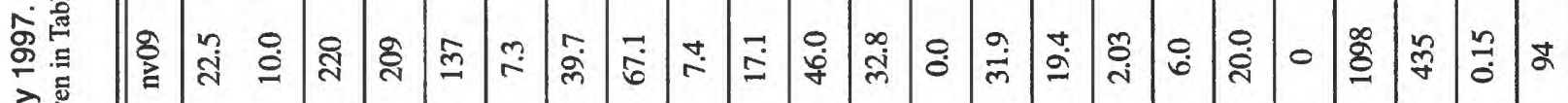

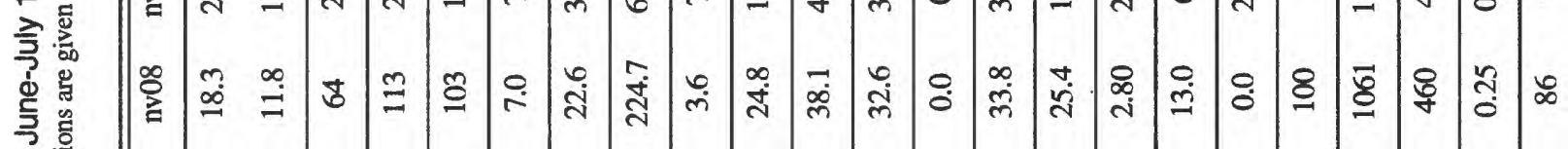

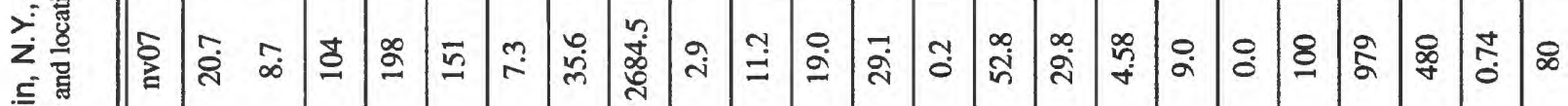

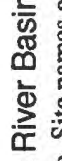

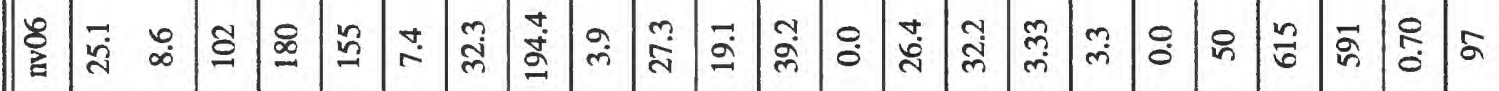

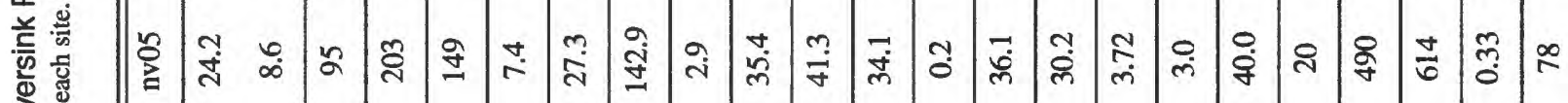
要要

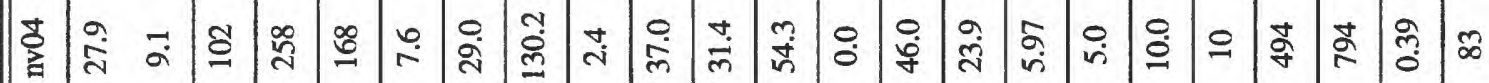

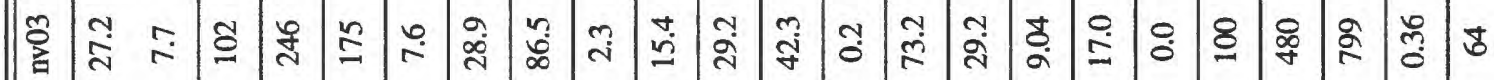

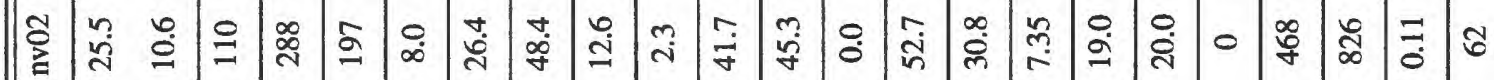

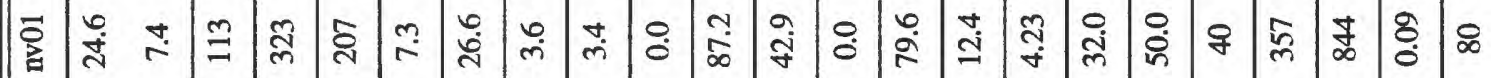

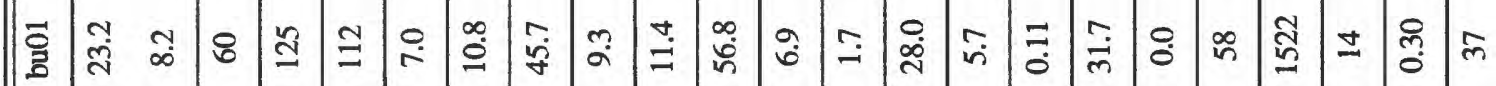

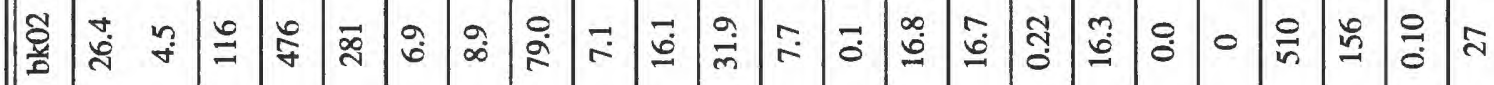
证 ब⿶凵

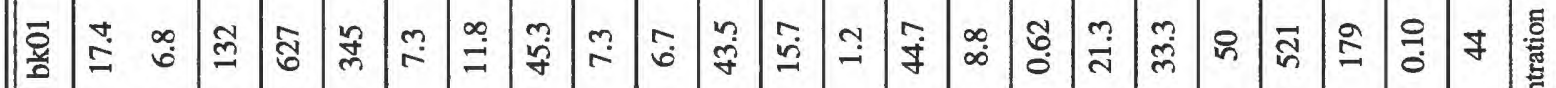

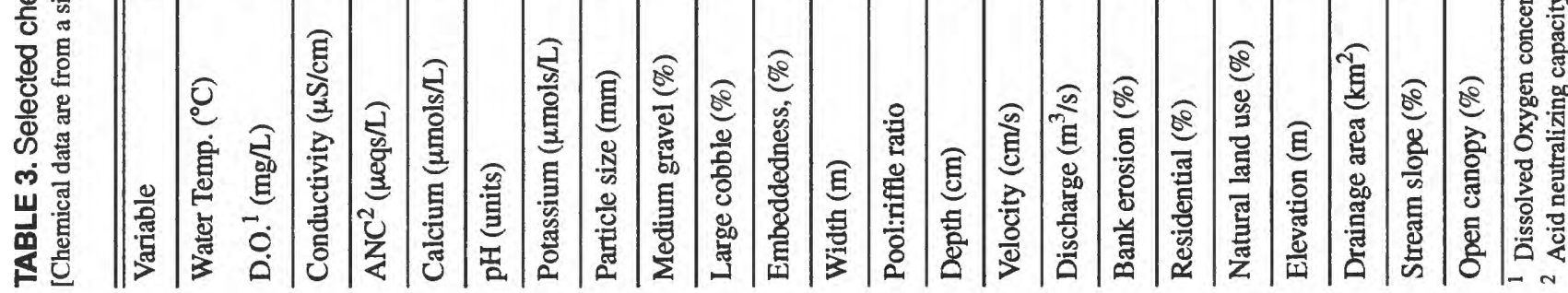




\section{Explanation}

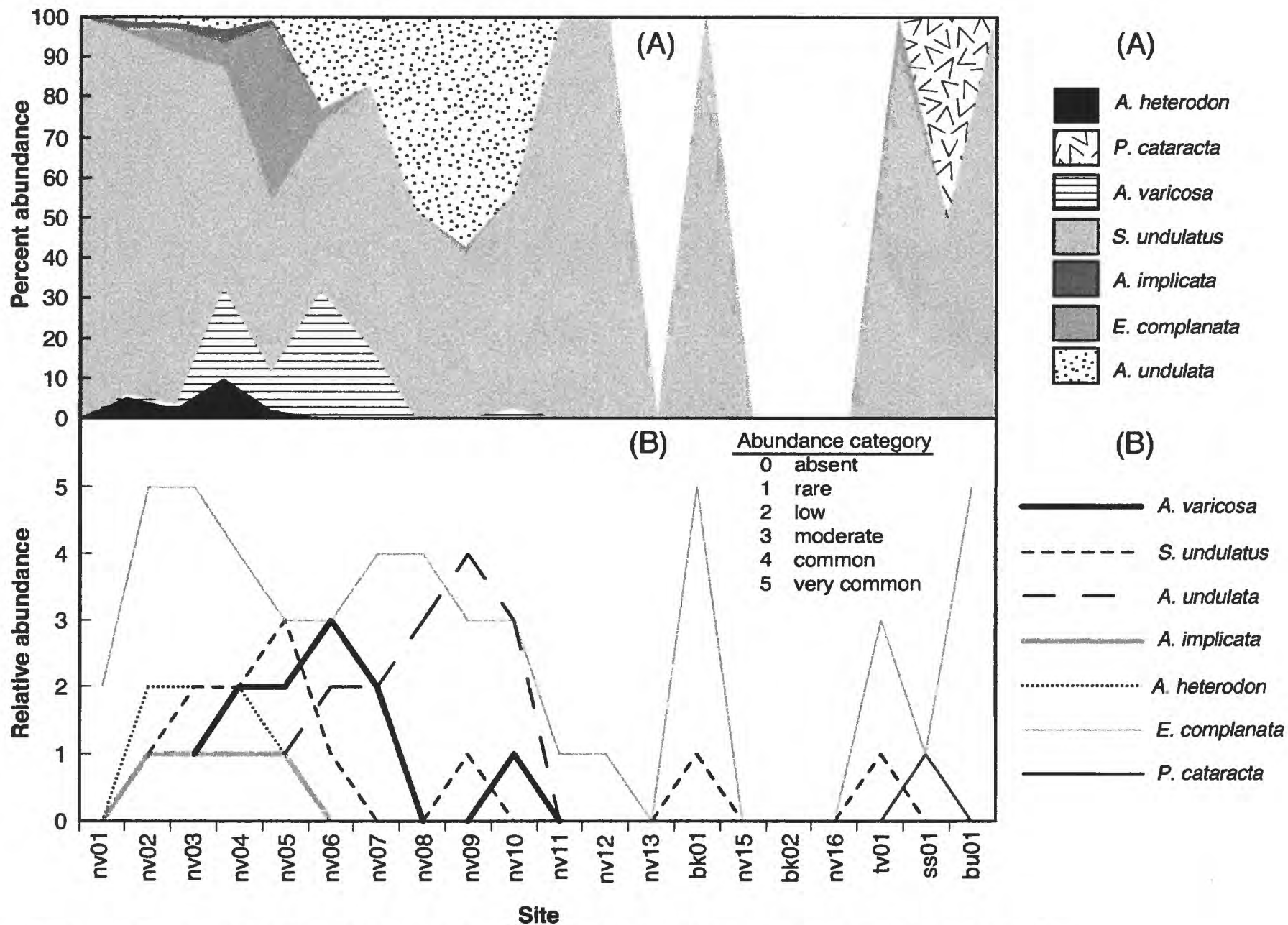

Figure 2. Percent total (A) and categorical relative (B) abundance of mussel species collected during surveys of 20 reaches in the Neversink River Basin, N.Y., June-July, 1997. (Sites are listed in order of drainage-area size, with largest on the left. Small tributary sites without mussels are omitted. Site locations are shown in Fig. 1.)

observed at any other site (Fig. 2). The absence of $P$. cataracta at the riverine sites was not unusual because the species is typically found in quiet and wellprotected ponds and marshes (Strayer and Jirka 1997). Abundances of Alasmidonta varicosa, Strophitus undulatas, and Alasmidonta undulata were low to common at most main-stem sites in the lower to middle reaches of the basin; $A$. undulata also was found at two tributary sites -- tv01 and bk01 (Fig. 2). A value of 1 was added to relative-abundance value for each species to retain sites with no mussels (musselsabsent category) during subsequent CCAs.

\section{Abundance of Macroinvertebrate Species}

Nearly 250 non-mussel macroinvertebrate taxa were observed at the 26 sites. From these, a total of 145 parent taxa were identified for further analyses; 120 taxa were used for correspondence analyses at the 20 sites where both the mussel communities and reach-habitat conditions were inventoried. The term "macroinvertebrates" signifies non-mussel benthic invertebrate taxa in the remaining text. Macroinvertebrate-species richness, EphemeropteraPlecoptera-Trichoptera (EPT) richness, and 


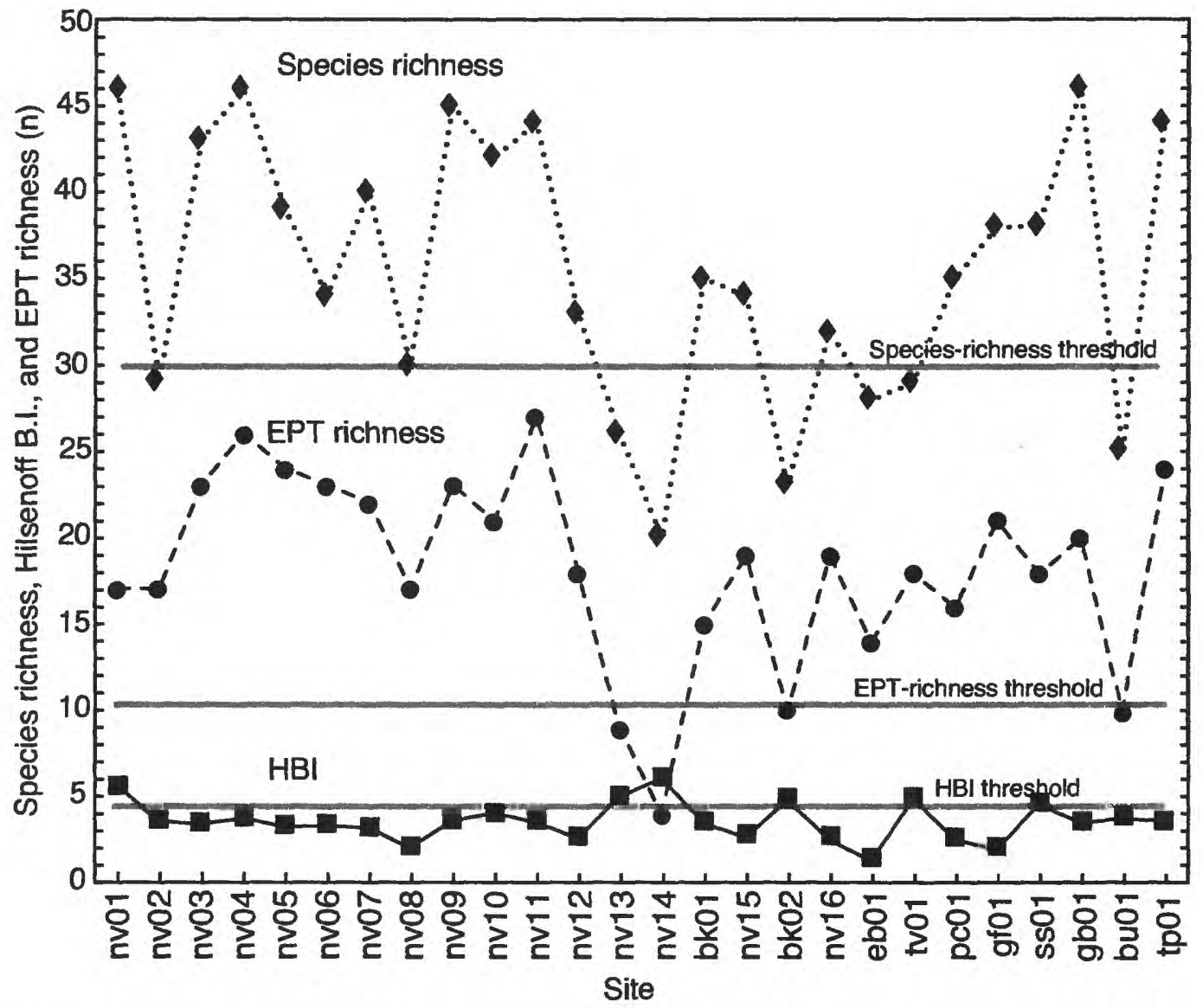

Figure 3. Species richness, EPT (Ephemeroptera, Plecoptera, and Trichoptera) richness, Hilsenhoff Index of Biotic Integrity (HBI), and New York State Department of Environmental Conservation (DEC) thresholds for slight water quality impacts at 26 sites in the Neversink River Basin, N.Y., July 1997. (Sites are ordered by drainage area, with largest to the left. Site locations are shown in Fig. 1.)

Hilsenhoff's Biotic Index (HBI) for each site are summarized in Fig. 3, in which New York State Department of Environmental Conservation (NYSDEC) thresholds for "slight" water-quality impacts, modified for 200-count samples, are given for each index. The HBI threshold is an upper limit, and the EPT and species-richness thresholds are lower limits. These thresholds were generally surpassed at nv01 (the Neversink River at Port Jervis), at nv13 and nv14 (immediately below the Neversink Reservoir), at tv01 (Sheldrake Stream, which was downstream from a sewage-treatment plant), at bk02 (the Basha Kill immediately below the Basha Kill Marsh), and at bu01 (upper Bush Kill) (Fig. 1). These findings suggest that macroinvertebrate communities could be affected by poor water quality or unsuitable physical habitat at several sites in the basin. These macroinvertebrate assemblages were unusual and data from several sites were excluded from certain CCA analyses to allow interpretation of the sources of dispersion among the remaining sites.

\section{Correspondence Analyses of Macroinvertebrate Species}

Unconstrained correspondence analyses (CA) of percent abundance data for macroinvertebrate species (taxa) from all 26 sites (Fig. 4A) and from 20 mainstem sites (Fig. 4B) indicate that environmental and spatial variables explained from 37 to $44 \%$ of the variation in the species matrix. Data from sites nv14, eb01, gf01, gb01, pc01, and tp01 were excluded from Fig. 4B because habitat was not assessed at these sites, which precludes constrained analyses. The first axis in 
Fig. 4A explained $11.8 \%$ of the variation in the species matrix and suggested a channel-size and (or) geochemical gradient between (a) sites with small channels with cold water, high conductivity, and low Ca concentrations, low ANC, and low $\mathrm{pH}$ and (b) sites with warm water, low conductivity, and high $\mathrm{Ca}$ concentrations, high ANC, and high $\mathrm{pH}$. The second axis in Fig. 4A explained $9.5 \%$ of the variation in the species matrix and suggested gradients between (a) site nv01 with high ANC and Ca concentrations, large depth of fines, slow water velocities, and very low channel slopes and (b) all other sites with low to moderate ANC and Ca concentrations, slow to fast water velocity, and steeper channel slopes. The first two axes in Fig. 4B explained $27 \%$ of the variation in the macroinvertebrate species matrix and identify gradients similar to that suggested when data from all 26 sites, (where macroinvertebrates were sampled) were analyzed. In both analyses, macroinvertebrate communities from sites nv01 and nv14 differed substantially from those at all other sites; this overly restricted site dispersion in ordinations and hindered interpretations. Data from nv01 were excluded from several CCAs to reduce the problem.

Four site classes were delineated from the distribution of mussel species (mussel-site groups) observed at each study site; these were: group 1 -- sites nv13, nv15, nv16, and bk02 (and nv14, eb01, gf01, gb01, pc01, and tp01, which are not shown in Fig. 4B) with no mussels; group 2 -- sites nv11, nv12, bk01, bu01, ss01, tv01, and nv01 with only E. complanata but occasionally with $E$. complanata and 1 or 2 individuals of another species; group 3 -- sites nv06, nv07, nv08, nv09, and nv10, with multiple (usually 4) mussel species, but no $A$. heterodon; and group 4 -sites nv02, nv03, nv04, and nv05 with multiple mussel species including $A$. heterodon (and A. implicata). Sites from groups 1 and 2 (without mussels or with only $E$. complanata) were generally at higher elevations and had smaller channel widths, slower (or faster) water velocities, higher (or lower) temperatures, and lower ANC values (excluding nv01) than sites from groups 3 and 4 (with multiple mussel species, either with or without $A$. heterodon) (Figs. 4A, 4B). Sites in group 3 were upstream of the Cuddebackville Dam and sites in group 4 were downstream of the Cuddebackville Dam. Plotting positions (based on the macroinvertebrate matrix) for sites of group 3 with multiple mussel species and no $A$. heterodon (nv06, nv07, and nv08, and nv09) were typically located at or near sites in group 4 with $A$. heterodon (Figs. 4A, 4B), and indicate that macroinvertebrate communities at many sites in these two groups were similar.

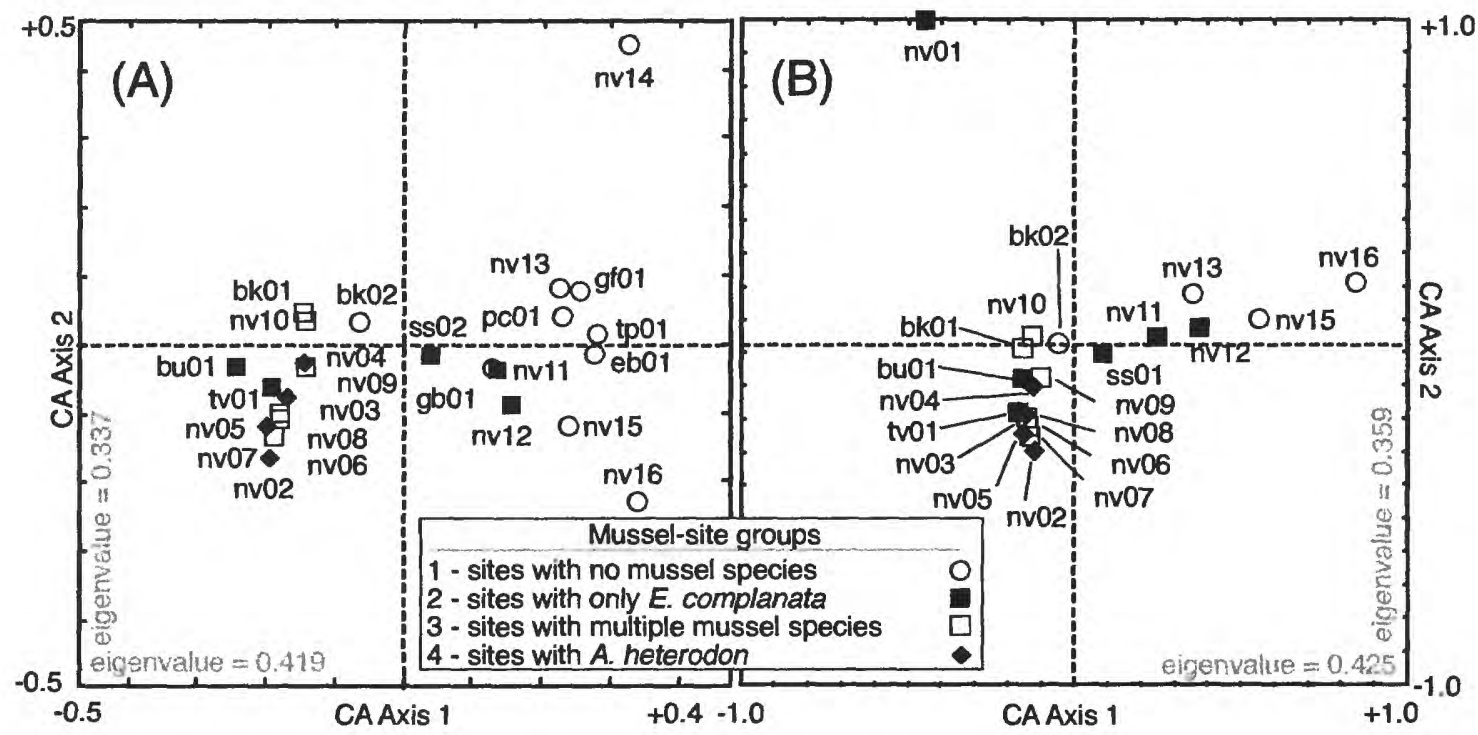

Figure 4. Unconstrained correspondence analysis (CA) ordination scatter plot of sites in the Neversink River, 1997, (A) based on a log-translated macroinvertebrate-species matrix at all 26 sites (nv01 is not shown but located at about -0.2 [CA Axis 1] and +0.75 [CA Axis 2]) and (B) based only on the 20 sites where habitat was characterized. Sites are categorized as those with (1) no mussel species, (2) E. complanata and more than 1 other 2 individuals of another species, (3) multiple mussel species but no $A$. heterodon, and (4) multiple mussel species and $A$. heterodon. 


\section{Canonical Correspondence Analyses of Macroinvertebrate Species}

If sites were presumed to be spatially independent, the CCA biplot of environmental variables in relation to similarity of macroinvertebrate taxa at 19 sites (Fig. 5A) shows how closely the sites and species (not displayed) were distributed along gradients for selected factors and, thus, how likely those factors were to affect or limit macroinvertebrateand mussel-species populations throughout the basin. Forward selection of environmental variables and long vectors (arrows) closely associated with the first two CCA axes (Axis 1 and Axis 2) in Fig. 5A show that variations in macroinvertebrate assemblages among sites were strongly related to differences in mean channel width, percent open canopy, $\mathrm{ANC}$, and $\mathrm{pH}$. Spatially structured environment explained $40.6 \%$ of the variability in species-environment relations; the first 2 CCA axes explained $24.1 \%$ of the variability, and, the $3 \mathrm{rd}$ and $4^{\text {th }}$ axes explained another $16.4 \%$ of the variability (Table 4A). Canonical coefficients of standardized-environmental variables with the four CCA axes show that Axis 1 depicted channel-width and open-canopy gradients; and Axis 2 depicted ANC and $\mathrm{pH}$ gradients (Table 5A).

The spatial factors, longitude and latitude ${ }^{3}$, explained $14.8 \%$ of variation in the macroinvertebratespecies matrix (Table 4B) and were significantly correlated with Axis 1 and Axis 2 (Table 5B). The Cuddebackville Dam, however, did not explain any variation in the macroinvertebrate-species matrix. When the effects of space were removed (using spatial covariables - Fig. 5B), pure environment explained $32.6 \%$ of the variation (Table 4C); when the effects of environmental variables were removed (using environmental covariables), pure space explained $14.8 \%$ of the variation in the macroinvertebratespecies matrix (Table 4B). The results of PCCAs (Fig. $6 \mathrm{E}$ ) indicate that $55.4 \%$ of the variation in the macroinvertebrate-species matrix were explained by environmental and spatial factors and that $44.6 \%$ of the variation could not be explained by measured factors. Additional PCCAs based on less restrictive criteria for selection of independent variables (not shown) indicate that as much as $68.1 \%$ of the variation in the macroinvertebrate species matrix could be explained by spatial and environmental factors.

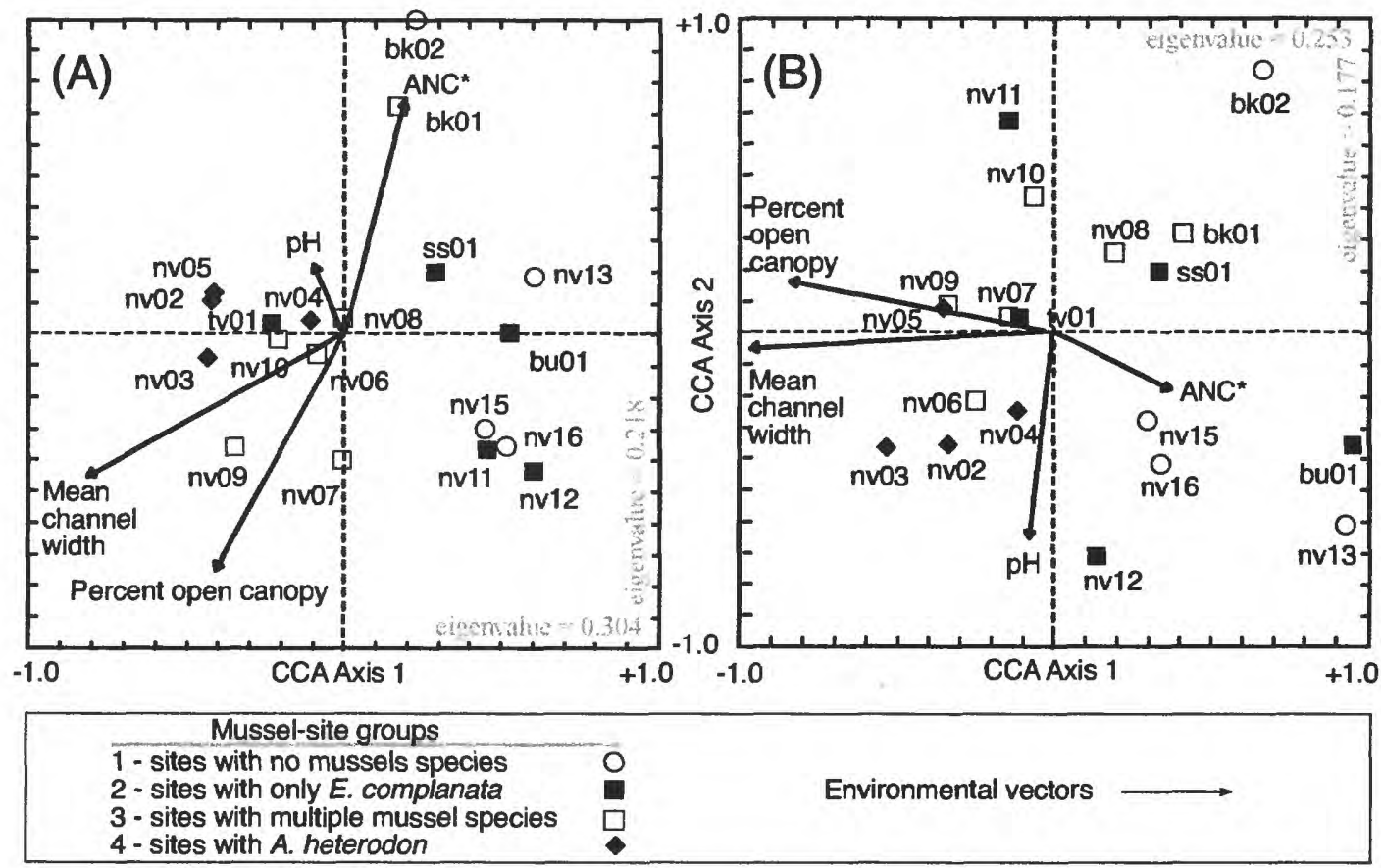

Figure 5. Canonical correspondence analysis (CCA) biplot of final environmental variables in relation to 19 sites in the Neversink River Basin, 1997. Plotting positions of sites are based on logtransformed percentage macroinvertebrate-species data and are constrained by (A) spatiallystructured environment and (B) pure environment (using spatial covariables). Sites are categorized as those with (1) no mussel species, (2) E. complanata and no more than 1 other 2 individuals of another species, (3) multiple mussel species but no A. heterodon, and (4) multiple mussel species and $A$. heterodon. (Data from site nv01 are excluded; variables that were log transformed are denoted with an asterisk.) 
TABLE 4. Summary of canonical correspondence analyses (CCA) showing the variance in (1) the log-transformed percentage macroinvertebrate species matrix at 19 sites (nv01 is excluded) and (2) the relative-abundance mussel species matrix at 20 sites explained by (A) spatially-structured environmental variables and either $(B)$ pure space or $(C)$ pure environment in the Neversink River Basin, 1997.

\begin{tabular}{|c|c|c|c|c|c|c|c|}
\hline \multirow[b]{2}{*}{$\begin{array}{l}\text { Canonical correspondence } \\
\text { analysis summary }\end{array}$} & \multicolumn{4}{|c|}{ Loadings } & \multirow{2}{*}{$\begin{array}{l}\text { Total } \\
\text { variance } \\
\text { (inertia) }\end{array}$} & \multirow{2}{*}{$\begin{array}{l}\text { Sum of all } \\
\text { unconstrained } \\
\text { EVs with } \\
\text { covariables }\end{array}$} & \multirow{2}{*}{$\begin{array}{l}\text { Sum of all } \\
\text { constrained } \\
\text { EVs with } \\
\text { covariables }\end{array}$} \\
\hline & $\begin{array}{r}\text { Axis } \\
1\end{array}$ & $\begin{array}{c}\text { Axis } \\
2\end{array}$ & $\begin{array}{c}\text { Axis } \\
3\end{array}$ & $\begin{array}{c}\text { Axis } \\
4\end{array}$ & & & \\
\hline \multicolumn{8}{|c|}{ A. Macroinvertebrate species and spatially structured environment } \\
\hline Eigenvalues (EVs) & 0.304 & 0.215 & 0.191 & 0.164 & 2.158 & na & 1.601 \\
\hline Percentage variance explained by each axis & 14.1 & 10.1 & 8.8 & 7.6 & & & \\
\hline $\begin{array}{l}\text { Cumulative percent of variance in species } \\
\text { data explained }\end{array}$ & 14.1 & 24.2 & 33.0 & 40.6 & & & 40.6 \\
\hline \multicolumn{8}{|c|}{ B. Macroinvertebrate species and pure space (with environmental covariables) } \\
\hline Eigenvalues for spatial relation & 0.179 & 0.141 & na & na & 2.158 & 1.281 & 0.320 \\
\hline Percentage variance explained by each axis & 14.0 & 9.0 & na & na & & & \\
\hline $\begin{array}{l}\text { Cumulative percent of variance of species } \\
\text { data explained. }\end{array}$ & 14.0 & 25.0 & na & na & & & 14.8 \\
\hline \multicolumn{8}{|c|}{ C. Macroinvertebrate species and pure environment (with spatial covariables) } \\
\hline Eigenvalues & 0.253 & 0.177 & 0.154 & 0.119 & 2.158 & 1.664 & 0.703 \\
\hline Percentage variance explained by each axis & 15.2 & 10.6 & 9.3 & 7.2 & & & \\
\hline $\begin{array}{l}\text { Cumulative percent of variance of species } \\
\text { data explained. }\end{array}$ & 15.2 & 25.6 & 35.1 & 42.3 & & & 32.6 \\
\hline \multicolumn{8}{|c|}{ D. Mussel species and spatially structured environment } \\
\hline Eigenvalues & 0.033 & 0.021 & 0.011 & 0.004 & 0.132 & na & 0.068 \\
\hline Percentage variance explained by each axis & 24.7 & 15.7 & 8.0 & 3.2 & & & \\
\hline $\begin{array}{l}\text { Cumulative percent of variance in species } \\
\text { data explained }\end{array}$ & 24.7 & 40.4 & 48.4 & 51.6 & & & 51.5 \\
\hline \multicolumn{8}{|c|}{ E. Mussel species and pure space (with environmental covariables) } \\
\hline Eigenvalues for spatial relation & 0.018 & 0.007 & 0.001 & na & 0.132 & 0.064 & 0.026 \\
\hline Percentage variance explained by each axis & 28.3 & 10.5 & 2.3 & na & & & \\
\hline $\begin{array}{l}\text { Cumulative percent of variance of species } \\
\text { data explained. }\end{array}$ & 28.3 & 38.8 & 41.1 & na & & & 19.7 \\
\hline \multicolumn{8}{|c|}{ F. Mussel species and pure environment (with spatial covariables) } \\
\hline Eigenvalues & 0.019 & 0.011 & 0.004 & 0.002 & 0.132 & 0.075 & 0.037 \\
\hline Percentage variance explained by each axis & 25.8 & 15.0 & 6.0 & 2.6 & & & \\
\hline $\begin{array}{l}\text { Cumulative percent of variance of species } \\
\text { data explained. }\end{array}$ & 25.8 & 40.8 & 46.8 & 49.4 & & & 28.0 \\
\hline
\end{tabular}


TABLE 5. Canonical coefficients for standardized environmental and spatial variables and covariables, and for a binary variable depicting a site's relation to the Cuddebackville Dam, with the first four CCA axes that depict similarity of nonmussel macroinvertebrate (percent abundance) and mussel species (relative abundance) among 19 to 20 sites (nv01 is excluded for macroinvertebrate CCAs) in the Neversink River Basin, 1997. (Significant correlations $(p \leq 0.05)$ between axes and variables are denoted by bold coefficients.)

\begin{tabular}{|c|c|c|c|c|}
\hline \multirow{2}{*}{$\begin{array}{l}\text { Environmental and } \\
\text { spatial variables }\end{array}$} & \multicolumn{4}{|c|}{ Canonical coefficients } \\
\hline & Axis 1 & Axis 2 & Axis 3 & Axis 4 \\
\hline \multicolumn{5}{|c|}{ A. Macroinvertebrate species and spatially structured environment } \\
\hline $\mathrm{pH}$ & 0.54 & -1.11 & -0.73 & -1.46 \\
\hline Mean channel width & -1.95 & 0.90 & -0.37 & 0.35 \\
\hline Percent open canopy & 1.25 & -0.91 & 1.72 & -0.08 \\
\hline Acid neutralizing capacity $\left(\log _{10}\right)$ & -0.85 & 1.31 & 1.73 & 0.56 \\
\hline \multicolumn{5}{|c|}{ B. Macroinvertebrate species and pure space (with environmental covariables) } \\
\hline Longitude & -0.06 & -1.41 & na & na \\
\hline Latitude $^{3}$ & 1.04 & 0.95 & na & na \\
\hline \multicolumn{5}{|c|}{ C. Macroinvertebrate species and pure environment (with spatial covariables) } \\
\hline$\overline{\mathrm{pH}}$ & 0.33 & -1.69 & -0.35 & 1.85 \\
\hline Mean channel width & -1.59 & -0.05 & -0.06 & -4.12 \\
\hline Percent open canopy & 0.47 & 0.81 & 1.11 & 3.54 \\
\hline Acid neutralizing capacity $\left(\log _{10}\right)$ & -0.31 & 1.34 & 2.29 & -2.32 \\
\hline \multicolumn{5}{|c|}{ D. Mussel species and spatially structured environment } \\
\hline Meain channel width & -0.93 & 0.42 & -0.84 & -0.36 \\
\hline Percent open canopy & 1.45 & 0.31 & 0.16 & 0.04 \\
\hline Conductivity $\left(\log _{10}\right)$ & 0.54 & 0.10 & -0.41 & 0.94 \\
\hline Mean bank width $\left(\log _{10}\right)$ & -0.59 & 0.81 & 0.21 & 0.46 \\
\hline \multicolumn{5}{|c|}{ E. Mussel species and pure space (with environmental covariables) } \\
\hline Longitdue & 0.76 & 2.72 & -2.39 & na \\
\hline Latitude & 1.47 & -2.14 & 1.50 & na \\
\hline Dam (binary variable) & 1.25 & 2.42 & 0.37 & na \\
\hline \multicolumn{5}{|c|}{ F. Mussel species and pure environment (with spatial covariables) } \\
\hline Mean channel width & -1.87 & 0.65 & -1.19 & 1.69 \\
\hline Percent open canopy & 1.28 & -1.71 & 1.04 & -1.38 \\
\hline Conductivity $\left(\log _{10}\right)$ & 0.14 & -0.53 & 0.92 & 0.74 \\
\hline Mean bank width $\left(\log _{10}\right)$ & -0.59 & 0.50 & 0.42 & 0.06 \\
\hline
\end{tabular}




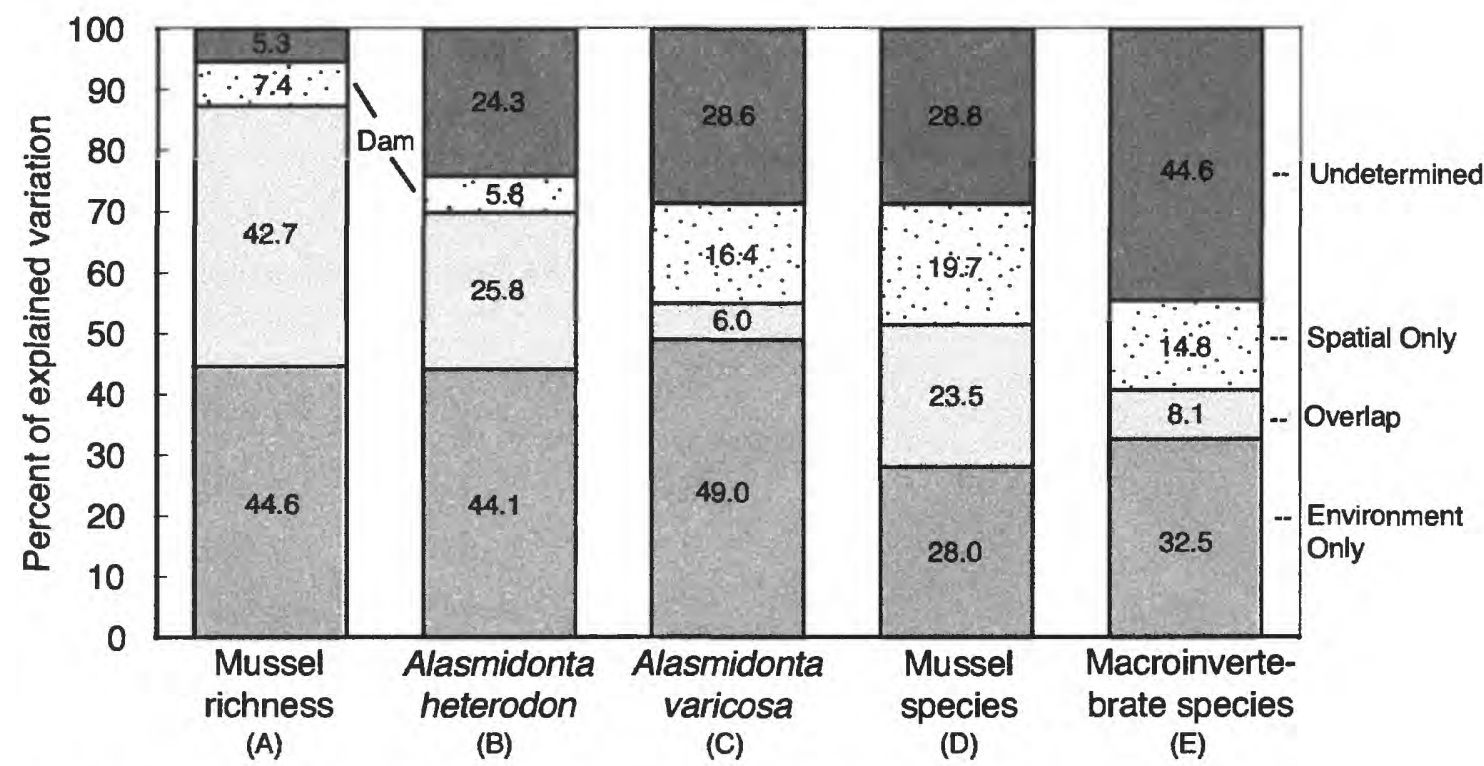

Figure 6. Percent of variation in (A) mussel-community richness and relative abundance for (B) A. heterodon and (C) A. varicosa populations explained by environmental and spatial variables using partial multiple regression analyses; and the percent variation in (D) relative abundance of the mussel-species matrix and $(E)$ percent abundance of the macroinvertebrate-species matrix explained by pure environment and pure space using partial canonical correspondence analyses at 19 to 20 sites in the Neversink River Basin, 1997. The percent of variation explained by overlap in environmental and spatial data, the Cuddebackville Dam, and which remain unexplained, are also estimated.

\section{Canonical Correspondence Analyses of Mussel Species}

If the Cuddebackville Dam had no affect on mussel-species distributions, and if sites were spatially independent, then the CCA biplot of environmental variables in relation to similarity of mussel taxa at all 20 sites (Fig. 7A) indicates that variations in musselspecies assemblages among sites were best explained by differences in mean channel width, percent open canopy, mean bank width, and water conductivity. Spatially structured environment explained $51.5 \%$ of the variability in the mussel-species matrix; the first four CCA axes explained 24.7, 15.7, 8.0, and 3.2 percent of the variability, respectively (Table 4D). Canonical coefficients of standardized environmental variables with the four CCA axes indicate that Axis 1 depicted gradients in percent open canopy and mean channel width; Axis 2 depicted a gradient in mean bank width; Axis 3 depicted a gradient in mean channel width; and Axis 4 depicted a gradient in conductivity (Table 5D). Differences among groups were relatively obscure, although sites from groups 1 and 2 generally had smaller channel and bank widths, lower conductivity, and lower percent open canopy than sites from groups 3 and 4 (Fig. 7A, Table 3).
The spatial factors - binary (dam) variable for a site's location either upstream or downstream from Cuddebackville Dam, latitude, and longitude, explained $19.7 \%$ of variation in the mussel-species matrix (Table 4E). The dam was significantly correlated with the $1^{\text {st }}$ two CCA axes (Table 5E). When the effects of these spatial variables were removed (Fig. 7B), pure environment explained 28\% of the variation in the mussel-species matrix (Table 4F). The results of PCCAs (Fig. 6D) indicate that $71.2 \%$ of the variation in the mussel-species matrix was explained by environmental and spatial factors, (23.5\% was overlap) and $28.8 \%$ of the variation was not explained by measured variables. If other environmental variables (e.g., drainage area, percent sand, channel slope, elevation, mean bank angle, $\mathrm{ANC}$, and conductivity) that add explanatory power were included in supplemental CCAs, then as much as $48 \%$ of the variability in the mussel-species matrix could be explained by pure environment. Alternative PCCAs using variables that add significantly $(p \leq 0.1)$ to explanatory power of models (not shown) suggests that as much as $94 \%$ of the variation in the mussel species matrix could be explained by spatial and environmental factors. 


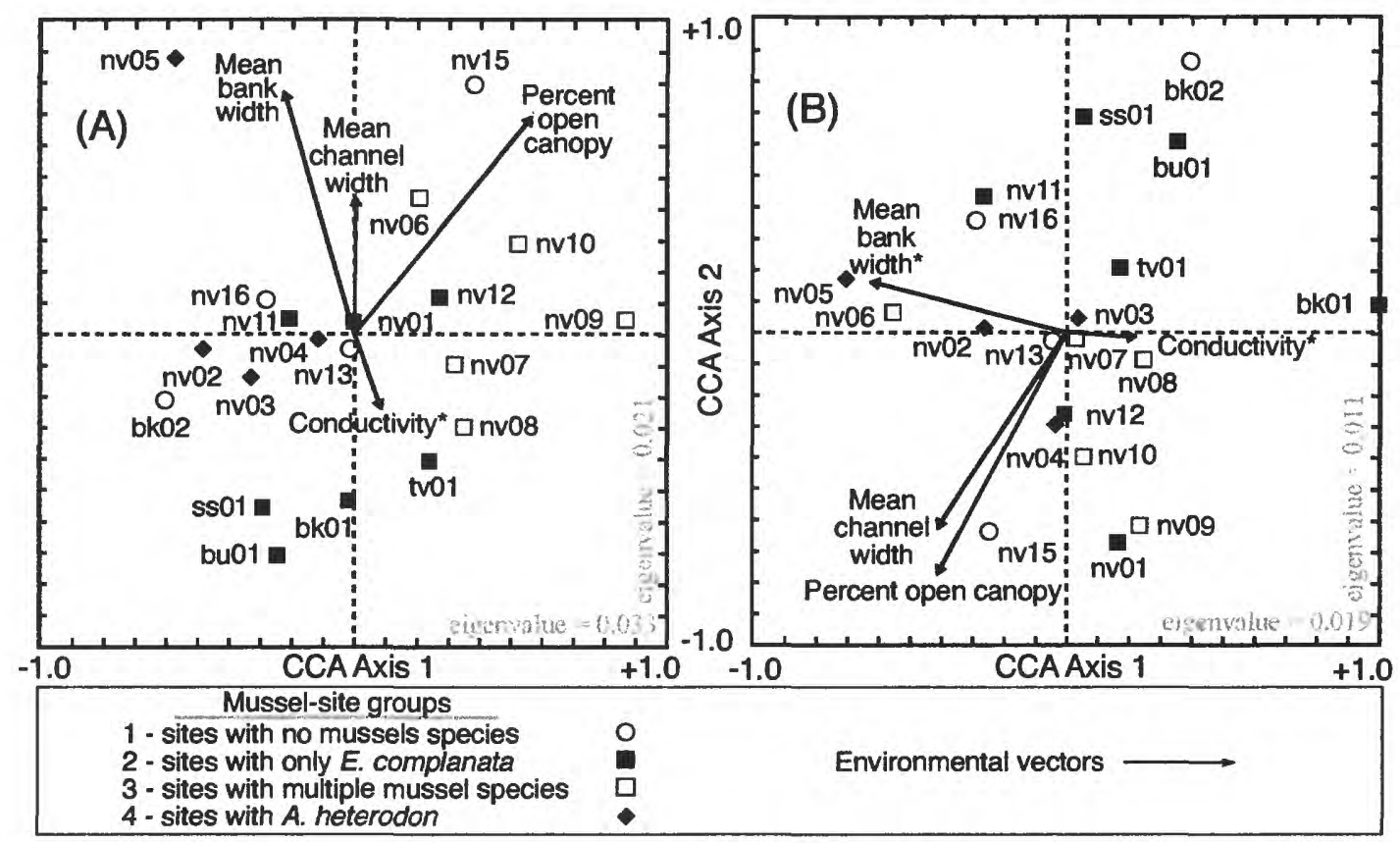

Figure 7. Canonical correspondence analysis (CCA) biplot of final environmental variables in relation to 20 sites in the Neversink River Basin, 1997. Plotting positions of sites are based on similarity of mussel-species assemblages and constrained by (A) spatially-structured environment and (B) pure environment (using spatial covariables). Sites are categorized as those with (1) no mussel species, (2) E. complanata and no more than 1 other 2 individuals of another species, (3) multiple mussel species but no $A$. heterodon, and (4) multiple mussel species and $A$. heterodon. (Variables that are log transformed are denoted with an asterisk.)

\section{Correlation and Regression Analyses}

Although nearly 100 original factors were characterized, 51 of which were analyzed by CCAs, strong multicorrelation among environmental factors restrict interpretation to relatively few key variables. Thus, the effects of all factors on macroinvertebrate and mussel communities could not be completely assessed in CCAs. Other variables that were highly correlated with key environmental factors that explained variability in macroinvertebrate and mussel species assemblages, might also affect certain mussel species more directly than the key environmental variables (identified by the CCAs). Key and correlated variables, along with unmeasured factors, effectively limit the distribution of most invertebrate species and the richness of mussel communities throughout the basin. A more robust analysis of the relations between invertebrate-species assemblages and environmental factors is possible through correlation and multiple regression analyses.

If spatial autocorrelation was ignored, results of simple regression or correlation analyses based on 51 mostly non-zero and normally distributed variables indicate that several factors identified by previous CCAs (and factors correlated with these variables), such as elevation, watershed area, $\mathrm{pH}$, stream discharge, and maximum channel width, individually explained from 24 to $58 \%$ of the variability in musselspecies richness in the basin (Table 6). Latitude alone explained $42 \%$ of the variability, and the dam explained $24 \%$ of the variability in mussel-species richness (Table 6). Results of multiple regression analyses are not summarized herein but indicate that combinations of water temperature, mean water velocity, maximum bank width, $\mathrm{K}$ and nitrate concentration, mean depth of fines, $\mathrm{pH}$, stream slope, percent sand, and type of bank material explained as much as $87.5 \%$ of the variability in mussel-species richness. Almost $95 \%$ of the variability could be explained when the dam and longitude were included in the environmental models. Results of partial MRAs indicate that (1) latitude or longitude does not improve upon the best environmental models, thus; space alone did not explain any of the variability in mussel-species richness, (2) overlap explained about $43 \%$ of the variability, and (3) $5.5 \%$ of the variability was 
TABLE 6. Pearson coefficients of correlation $(R)$ for environmental and spatial variables with the number (richness) of mussel species, and with the relative abundance of $A$. varicosa and $A$. heterodon populations at up to 20 sites in the Neversink River Basin, 1997. Most correlations were significant $(p \leq 0.05)$ at $R>0.43$ using 19 degrees of freedom.

\begin{tabular}{|c|c|c|c|}
\hline \multirow[b]{2}{*}{ Environmental and spatial variables } & \multirow[b]{2}{*}{ Mussel species richness } & \multicolumn{2}{|c|}{ Relative abundance } \\
\hline & & A. varicosa & A. heterodon \\
\hline Water temperature & 0.60 & ns & 0.53 \\
\hline pH & 0.76 & 0.45 & 0.63 \\
\hline Potassium & 0.63 & 0.55 & ns \\
\hline Sulfate $\left(\log _{10}\right)$ & 0.50 & ns & ns \\
\hline Nitrate $\left(\log _{10}\right)$ & 0.49 & ns & ns \\
\hline Mean water velocity & 0.54 & 0.65 & 0.64 \\
\hline SD water velocity & ns & 0.62 & ns \\
\hline Mean channel width & 0.66 & 0.53 & ns \\
\hline Mean bank erodability & ns & -0.46 & ns \\
\hline Percent large cobble & ns & 0.44 & ns \\
\hline Percent small boulders $\left(\log _{10}\right)$ & ns & 0.47 & ns \\
\hline Elevation & -0.61 & -0.47 & -0.55 \\
\hline Percent small sand $\left(\log _{10}\right)$ & ns & -0.56 & ns \\
\hline Dam (binary variable) & 0.50 & ns & 0.66 \\
\hline Latitude & -0.65 & -0.46 & -0.54 \\
\hline Longitude & ns & ns & ns \\
\hline Latitude $^{2}$ & -0.65 & -0.46 & -0.54 \\
\hline Latitude $\mathrm{x}$ longitude & -0.65 & -0.47 & -0.55 \\
\hline Longitude $^{2} \mathrm{x}$ latitude & -0.65 & -0.47 & -0.56 \\
\hline Latitude $^{2} \mathrm{x}$ longitude & -0.65 & -0.47 & -0.55 \\
\hline Latitude $^{3}$ & -0.65 & -0.46 & -0.54 \\
\hline
\end{tabular}

unexplained by measured variables (Fig. 6A).

Alternative models suggest, however, that the dam alone explained about $7.2 \%$ of the variability in mussel-species richness (Fig. 6A). These findings suggest that (1) the Cuddebackville Dam had a small but significant affect on mussel-species distributions, (2) spatial juxtaposition of each site in respect to other sites may have affected richness of mussel communities, and (3) macrohabitat and water-quality factors strongly affected mussel-species distributions throughout the basin.

Regression analyses indicate that mean water velocity and SD of water velocity alone explained 38 to $42 \%$ of the variability in relative abundance of $A$. varicosa populations at seven sites in the basin (Table 6). These two variables, in combination with elevation, water temperature, percent sand, and percent large gravel, explained as much as $84 \%$ of the variability in relative abundance of their populations. The
Cuddebackville Dam had no effect, but latitude explained about $21 \%$ of the variability (Table 6). Results of partial MRA indicate that space alone explained $16.4 \%$, environment alone explained $49 \%$, and overlap explained $6 \%$, of the variability in relative abundance of $A$. varicosa populations; $28.6 \%$ of the variability was unexplained by measured variables (Fig. 6C).

Although A. heterodon populations were sampled from only 4 sites, regression analyses show that either $\mathrm{pH}$ or mean water velocity explained about $40 \%$ of the variability in relative abundance of their populations (Table 6). These variables, in combination with water temperature, SD of water velocity, discharge, maximum depth of fines, percent small cobble, percent open canopy, channel width (minimum, maximum, or mean), maximum channel depth, mean particle size, and nitrate explained as much as $92 \%$ of the variability in relative abundance of $A$. heterodon populations. 
Latitude or longitude explained about $31 \%$, and the dam alone explained about $44 \%$ of the variability in relative abundance of $A$. heterodon populations (Table 6 ). The dam, combined with other factors, explained as much as $75.7 \%$ of the variability in A. heterodon populations. Partial MRAs indicate that latitude or longitude did not improve upon the best environmental models; thus, (1) space alone explained none of the variability in $A$. heterodon populations, (2) overlap explained $25.8 \%$ of the variability, and (3) $24.3 \%$ of the variability was unexplained by measured variables (Fig. 6B). Alternative models suggest, however, that the dam alone explained about $6 \%$ of the variability in A. heterodon populations (Fig. 6B). These findings suggest that the Cuddebackville Dam, latitude, $\mathrm{pH}$, temperature, and macrohabitat factors such as mean water velocity and mean channel width affected $A$. heterodon populations in the Neversink River Basin.

\section{Differences in Environmental Variables among Mussel-Site Groups}

Results of nonparametric Kruskal-Wallis tests based on the 26 final environmental variables (excluding data from nv01 and bk02) indicate that water temperature, $\mathrm{pH}$, concentration of $\mathrm{SO}_{4}{ }^{2-}, \mathrm{NO}_{3}{ }^{-}$, and $\mathrm{K}$, percent small gravel, mean channel width, maximum channel width, mean water velocity, discharge, elevation, drainage area, and percent open canopy differed significantly $(p \leq 0.05)$ among sites from the four mussel-site groups. Several variables that may have affected the distribution of macroinvertebrate taxa and mussel species (e.g., conductivity, ANC, mean bank width, and percent sand) did not differ significantly among all groups. Overlap in medians and their $95 \%$ confidence intervals (CIs) for several environmental variables (Fig. 8) indicate that, except for water temperature, most key variables at sites in groups 3 and 4 did not differ significantly. Water temperature (based on a single sample from each site) differed between sites in groups 3 and 4, but not between sites from group 2 (sites with only $E$. complanata) and sites in groups 3 and 4 (Fig. 8). Median water velocity and median channel width for sites in groups 3 and 4 were significantly greater than that at sites from group 2 (Fig. 8). Potassium and calcium concentrations (both were correlated with ANC) and water temperature were also significantly higher at sites in groups 3 and 4 than at sites from group 1 (with no mussel species) (Fig. 8). Overall, results of Kruskal-Wallis tests and the box and whisker plots (Fig. 8) demonstrate that environmental factors that explained most of the variability in the macroinvertebrate-and musselspecies assemblages did not differ significantly between sites in groups 3 and 4, but assemblages at these two sites often differed significantly from that found at sites from groups 1 and 2 .

\section{DISCUSSION}

Results of correspondence and regression analyses suggest that water-quality, channel, and macrohabitat characteristics (e.g., mean channel width, percent open canopy, mean bank width, ANC, $\mathrm{pH}$, conductivity, and several other factors), spatial structure (e.g., latitude and longitude), the Cuddebackville Dam, and physiographic features (e.g., site elevation) affected the richness of mussel communities and the abundance of $A$. heterodon populations in the Neversink River Basin. Strong relations among the evaluated variables and the abundance of mussel species and mussel richness imply that these factors limit or govern mussel-species populations in the basin, although direct cause-andeffect relations cannot be defined, and mechanisms remain speculative. The similarity in macroinvertebrate assemblages and environmental conditions at main-stem sites above and below the Cuddebackville Dam, and the significant effect of the dam on the richness of mussel species and the relative abundance of $A$. heterodon populations further indicate that it could restrict $A$. heterodon (and possibly $A$. implicata) populations to the lower reaches of the basin. Two of the key environmental factors -- mean channel width and percent open canopy explained most of the variability in the macroinvertebrate- and mussel-species matrices during respective CCAs, which supports the hypothesis that macroinvertebrate and mussel communities were affected similarly by the same environmental factors.

\section{Mussel-Community Richness}

Several macrohabitat and water-quality factors appear to affect the distribution of mussel species and the richness of mussel communities throughout the Neversink River Basin. Mussel richness appears to be affected primarily by the percent open canopy, mean channel width, mean bank width, and conductivity; but also was correlated with $\mathrm{pH}, \mathrm{ANC}, \mathrm{K}$ concentration, mean water velocity, water temperature, elevation, latitude, and orientation to the Cuddlebackville Dam. 

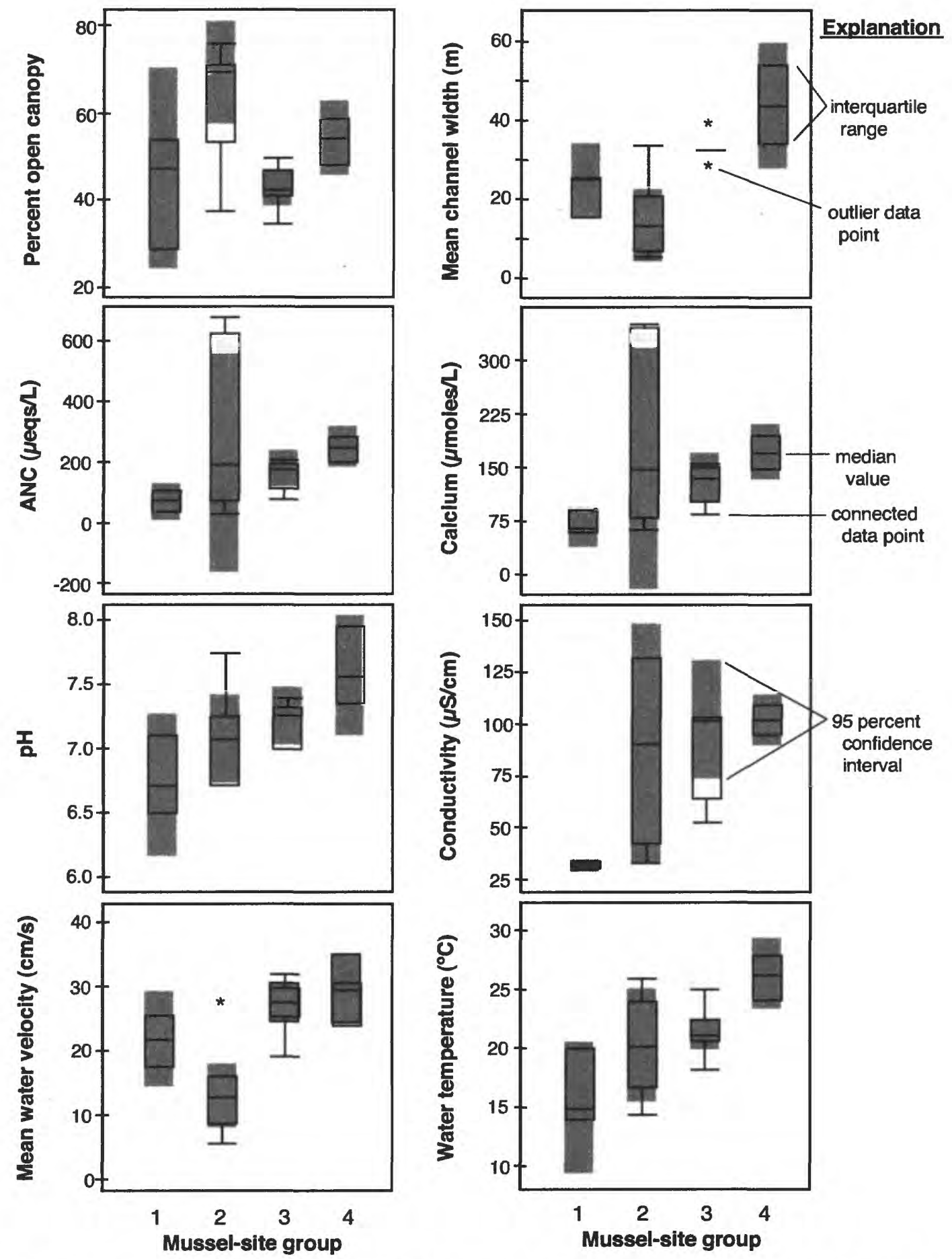

Figure 8. Box and whisker plots showing the interrelations of select final environmental variables among Neversink River sites, (excluding nv01 and bk02) from the four mussel-site groups. Sites are categorized as those with (1) no mussel species, (2) E. complanata and no more than 1 other 2 individuals of another species, (3) multiple mussel species but no A. heterodon, and (4) multiple mussel species and A. heterodon.

Other investigations have found relations between the richness of mussel communities and microhabitat factors, landscape characteristics, and physiographic factors, but few noted strong relations between macrohabitat factors and the richness of mussel species or the distribution of individual mussel-species populations (e.g., Vannote and Minshall 1982; Strayer and Ralley 1993; Strayer and others, 1994; Layzer and Madison 1995; Strayer 1999). The distribution of mussel species in the Salmon River, Idaho, was partly 
regulated by sediment stability (Vannote and Minshall 1982). Similarly, the patchy distribution of mussel beds under favorable or marginal environmental conditions in the Neversink River Basin has been hypothesized to result from the stability of stream sediments during high flows (Strayer and Ralley 1991). A recent study in the lower Neversink Basin showed that mussel-sized stones remain in mussel beds after large storm-flows and over periods of several years, whereas those at adjacent sites (within meters) containing no mussels were buried or transported downstream (Strayer 1999). Others have found that (1) seemingly important factors such as calcium concentration and stream size were not good predictors of Unionidae species richness (Strayer and Ralley 1991), and (2) water depth, organic content and granulometry of sediment, distance from shore, and concentration of particulate organic matter in freshwater tidal environments did not differ significantly with the distribution of five mussel species and none explained much of the variability in mussel-species abundance (Strayer and others, 1994). Related studies have shown that water depth and velocity were correlated with the distribution of mussel species at base flows, and that shear stresses at low and moderate flows during the period of juvenile settlement, were significantly correlated with mussel abundances at sites along a 4th-order stream in the Cumberland River Basin, KY (Layzer and Madison 1995). Shear stress, water velocity, stream discharge, and certain substrate particle sizes also had been shown or hypothesized to restrict mussel species to stable patches (microhabitats) in suitable reaches (Strayer and others, 1994; Strayer 1993; Strayer and Ralley 1993). The findings from the present study and others suggest that reach conditions at moderate to high flows might be critical factors governing the distribution of mussel species and the richness of mussel communities in lotic systems.

The reasons why most studies generally uncover only weak associations among environmental factors and mussel distributions and abundances may be that critical micro- and macro-habitat or biological factors are not measured nor evaluated. For example, more than $50 \%$ of the variation in the mussel species assemblages at 36 sites across the Red River drainage basin of Texas was attributed, at least in part, to the distribution and abundance of fish species (Vaughn and Taylor 2000). Fish assemblages, pure space, and pure environment explained $15.4,16.1$, and 7.8 percent of the variation in the mussel-species matrix, respectively; overlap among the three categories explained $40 \%$ of the variation and $20.4 \%$ of the variance was unexplained (Vaughn and Taylor 2000). In addition, water depths, velocities, and bed shear stresses are potentially important independent variables, but they are associated with channel forming or effective discharge levels, occur primarily under high-flow conditions, and are difficult to quantify.

\section{Abundance and Distribution of Alasmidonta varicosa Populations}

Partial multiple regression analyses indicate that (1) environmental factors explained almost $50 \%$ of the variability in relative abundance of $A$. varicosa populations, (2) these populations were primarily affected by mean water velocity or the variability (SD) of water velocity, and (3) they also appeared to be affected by elevation, water temperature, percent sand, and percent large gravel in the Neversink River.

Alasmidonta varicosa populations were apparently not affected by variations in water quality nor by the Cuddebackville Dam, but were affected by space (latitude). Less restrictive multiple regression analyses $(p<0.1)$ indicate that combinations of environmental and spatial factors could explain as much as $84 \%$ of the variability in $A$. varicosa populations and suggest that their populations were vigorous and not subject to significant stresses from any of the measured factors. Because the species occurs both upstream and downstream of the Cuddebackville Dam, the populations either were present in the middle reaches of the basin before the dam was constructed, or the host-fish species can traverse the structure in both directions. In either case, the low head dam did not appear to limit their populations. The Neversink Reservoir in the upper reaches of the basin (Fig. 1), however, may have had, and may still have a considerable effect on the distribution of $A$. varicosa populations in the basin, as discussed in a later section.

\section{Abundance and Distribution of Alasmidonta heterodon Populations}

Simple and partial multiple-regression analyses indicate that environmental factors explained about $44 \%$ of the variability in relative abundance of $A$.

heterodon populations and that their populations were primarily affected by $\mathrm{pH}$ and mean water velocity, but were also influenced by water temperature, SD of water velocity, discharge, maximum depth of fines, 
percent small cobble, percent open canopy, channel width, maximum channel depth, mean particle size, and nitrate concentration at four sites in the Neversink River Basin. Their populations also appeared to be affected by the Cuddebackville Dam as well as by latitude and longitude. Alternative multiple-regression analyses indicate that combinations of environmental factors explained as much as $92 \%$ of the variability in relative abundance of $A$. heterodon populations and that the dam alone explained about 6 percent of the variability. These findings, in conjunction with those for mussel richness, suggest that the dam, latitude, $\mathrm{pH}$, temperature, elevation, conductivity, and macrohabitat factors such as mean water velocity, percent open canopy, and mean channel width, affected the distribution and relative abundance of $A$. heterodon populations most strongly in the Neversink River Basin.

\section{Long-term Perspective for Endangered Alasmidonta heterodon Populations}

The only apparent water-quality concern for endangered mussels in the Neversink Basin at this time is the potential effects that increased stream acidification (from acidic deposition) might have on ANC, acidity, and calcium (Ca) concentrations in reaches below the reservoir. The Neversink is one of few Catskill Mountain rivers that becomes strongly acidified in the upper reaches (Murdoch and Stoddard 1992). Significant decreases in stream-water $\mathrm{Ca}$ concentrations over the past 30 years have been related to acid deposition and $\mathrm{Ca}$ depletion of soils in the upper reaches of the basin (Lawrence and others, 1999). Direct effects of chronic and episodic acidification have also been identified as a serious threat to fish communities at sites upstream from the Neversink Reservoir (Baldigo and Murdoch 1997, Baldigo and Lawrence 2000). Sites eb01 and nv15 above the reservoir, and sites nv10 through nv14, below the reservoir (Fig. 1), also have relatively low ANC, $\mathrm{pH}$, and $\mathrm{Ca}$ concentrations (Table 3 ). Base-flow ANC values of $100 \mu \mathrm{eq} / \mathrm{L}$ and lower indicate that negative ANC levels, and pH values near 5.0 could be anticipated during springtime high-flow conditions at main-stem sites nv08 and nv10 through nv14. The effects of lowered ANC, $\mathrm{pH}$, and $\mathrm{Ca}$ concentrations and increased metal mobilization on mussel survival, shell erosion, and species distributions are unknown, but could potentially be detrimental if long-term decreases in ANC and $\mathrm{Ca}$ concentration observed at sites in the upper basin (Lawrence and others, 1998) were extended to the middle and lower reaches of the basin. Such changes in water quality across the middle and lower reaches of the basin would be possible only if atmospheric deposition of acids worsen.

The major concern pertaining to dwarf wedgemussel populations (and habitat) in the lower basin is the Cuddebackville Dam (The Nature Conservancy 1999). The low-head dam may presently limit expansion of $A$. heterodon populations because it blocks upstream movement of the tessellated darter (Etheostoma olmstedi), which is a known host for the glochidea (larval) life stages of the dwarf wedgemussel (Michaelson and Neves 1995). It also blocks upstream migration of anadromous American shad (Alosa sapidissima), hickory shad (Alosa mediocris), and striped bass (Morone saxatilis), which occur in the lower basin. Expansion of $A$. heterodon populations might be possible if part, or all, of the dam was removed to allow for passage of its host-minnow species. In addition to blockage issues, a catastrophic failure of the dam during a large flood could potentially generate a bedload-sediment pulse that might affect $A$. heterodon populations in the lower basin. The dam is holding back only about $35 \mathrm{~m}^{3}$ of coarse bed sediments (W.F. Coon, U.S. Geological Survey, written communication, 1998). Therefore, the amount of sediment mobilized due to its failure would be limited and, burial of $A$. heterodon individuals would pose a threat only to their local populations.

\section{Effects of the Cuddebackville and Neversink Dams on Alasmidonta heterodon Populations}

The Cuddebackville Dam may restrict the distribution and relative abundance of $A$. heterodon (and A. implicata) populations in the basin by limiting upstream passage of at least one host-fish species (tessellated darter). The absence of $A$. heterodon above the dam and the presence of $A$. varicosa at sites above and below the dam are somewhat perplexing because both mussel species use closely related fish species as hosts (Strayer and Jirka 1997). At least two resident fish species, the longnose dace (Rhinichthys atratulus) and the slimy sculpin (Cottus cognatus) are know hosts for $A$. varicosa and the mottled sculpin (Cottus bairdi) is a known host for A. heterodon (Strayer and Jirka 1997). Presumably, either $A$. varicosa has been present upstream from the Cuddebackville Dam since before the early 1800 s when the dam was first built, or one of the host species is specific to A. varicosa and can negotiate the dam's low head. The absence of $A$. heterodon upstream from 
the dam, where habitat appears to be suitable, suggests that either movement of its host fish species is blocked by the dam, or other environmental conditions not assessed in this study limit their distributions and were unsuitable for this species near and upstream from the Cuddebackville Dam.

The Neversink Reservoir may have had positive and (or) negative effects on abundances and distributions of mussel populations. Since preconstruction mussel data are unavailable to test for trends or changes, any effects are speculative. For example, decreases in the frequency and magnitude of storm-flows in reaches downstream from the Neversink Reservoir (Fig. 1), since its completion in about 1955, have produced large decreases in annual peak discharges (and decreased base flows) in the middle and lower reaches of the basin. Instantaneous peak flows (highest flows recorded each year) decreased from an average of about $310 \mathrm{~m}^{3} / \mathrm{s}$ $\left(\mathrm{SD}=170 \mathrm{~m}^{3} / \mathrm{s}\right)$ before 1955 to about $150 \mathrm{~m}^{3} / \mathrm{s}$ $\left(\mathrm{SD}=65 \mathrm{~m}^{3} / \mathrm{s}\right)$ thereafter at a USGS continuousdischarge gage at site nv04; these decreases have increased hydrologic and channel stability and decreased bed-sediment loads in the middle and lower reaches of the basin. Dampened discharge peaks and increased substrate stability could be favorable for the establishment and long-term maintenance of mussel beds. Assuming the stable flow and substrate conditions permitted new mussel species and beds to become established throughout the basin, then the Cuddebackville Dam may have only recently become a real or coincidental barrier to potential expansion of A. heterodon populations.

Alternatively, by separating river segments and disrupting fish-species movements, water quality, and the natural thermal, sediment-transport, and hydrology regimes in the middle basin, the Neversink Reservoir has likely affected biodiversity and ecosystems across much of the basin. Assuming that diverse mussel assemblages existed throughout the basin before the reservoir was constructed, then, the effects as evidenced by present distributions would have been extensive. These circumstances seem likely because evidence of negative impacts of impoundments on mussel and macroinvertebrate populations is the norm rather than the exception (Anonymous 1997, Richter and others, 1997a). As an example, community richness and abundance of mussel species were found to increase with distance downstream from several impoundments along a 240-km section of the Little River in Oklahoma (Vaughn and Taylor 1999).

\section{Implications for Management of Natural Resources in Impounded Rivers}

The possibility that the two impoundments might have had beneficial as well as adverse effects on populations of threatened and endangered mussel species in the Neversink Basin has widespread implications for watershed and reservoir management and for ecosystem restoration. Dams have been found to not only block fish migration and alter downstream riverine habitat, they significantly change watertemperature regimes, alter water quality, increase hydrologic and sediment stability, and generally transform biological communities in riverine systems worldwide (Anonymous 1997, Richter and others, 1997a). The present study found that the Cuddebackville Dam could potentially restrict the distribution of one or more mussel species in the lower Neversink River Basin. The Cuddebackville Dam may only limit dwarf wedgemussel populations, however, because the Neversink Reservoir has increased hydrologic and sediment stability, which in turn might have increased habitat suitability for certain mussel species in the lower and middle reaches of the basin.

Changes in sediment transport, channel hydrogeomorphology, and thermal regimes due to the Neversink Dam have broad implications for aquatic ecosystem across the lower and middle reaches of the basin. The possibility that one or more mussel species expanded their range in the basin was only a small fraction of the biotic responses that probably took place when the upper basin was impounded. A river's flow regime is crucial to sustaining its native biodiversity and ecological integrity (Richter and others, 1996; Poff and others, 1997). The flow regime of a river controls physical and chemical parameters such as water temperature, channel geomorphology, and habitat diversity. Changes in flow linked to releases from reservoirs and dams often change the timing, duration and frequency of low and high water conditions (flooding and drought regimes), alluvial groundwater movements and water-table fluctuations (Richter and others, 1998). These alterations modify the distribution and availability of riverine habitat and cause cascading effects throughout the ecosystem (Poff and others, 1997; Richter and others, 1996; Richter and others, 1997b). The severe loss of seasonal flow peaks and changes to the timing of annual 
maximum and minimum flows in the Neversink River, though undocumented, has probably affected aquatic species that use flow cues for spawning, migration, and egg hatching, as well as the distribution of native fish and invertebrate species, and the structure and function of aquatic communities in parts of the basin.

Findings from this investigation further our understanding of mussel and habitat relations and should aid in management of water resources and the protection of rare and common mussels in the Neversink and in similar rivers of North America. Although little historic invertebrate data were available to confirm biotic changes that might have taken place in the Neversink River, the reduced range and variation of flow magnitudes may have stabilized flow conditions sufficiently to allow a few species to flourish, but at the probable expense of native biodiversity throughout the river system. Some semblance of original biodiversity and ecosystem integrity might be reconstituted in the Neversink and in comparable regulated rivers if water releases from reservoirs could be managed to approximate certain components of historic flow regimes. In an era of stream and ecosystem restoration, both the negative effects, and positive management potential of impoundments need to be evaluated before plans to restore natural biodiversity and hydro-geomorphology in riverine systems are implemented.

\section{Acknowledgements}

We wish to thank the O'Connell Foundation, which partly funded this study. We also extend thanks to the Town of Thompson and Anthony Cellini for project support, Orange County Department of Parks, Recreation, and Conservation and the many landowners in the basin who permitting access to the Neversink through their property, and Colin Apse, Alton Anderson, Gretchin Wall, Dave R. Smith, and Dave L. Strayer for technical assistance.

\section{REFERENCES CITED}

Anonymous, 1997, Effects of dams on downstream resources explored: Fisheries, v. 22, no. 2, p. 46-47.

Baldigo, B.P., and Lawrence, G.B., 2000, Composition of fish communities in relation to stream acidification and habitat in the Neversink River, New York: Transactions of the American Fisheries Society, v. 129, no. 1, p. 60-76.
Baldigo, B.P., and Murdoch, P.S., 1997, Effect of stream acidification and inorganic aluminum on mortality of brook trout (Salvelinus fontinalis) in the Catskill Mountains, New York: Canadian Journal of Fisheries and Aquatic Sciences, v. 54, no. 3, p. 603-615.

Bode, R.W., Novak, M.A., and Abele, L.E., 1996, Methods for rapid biological assessment of streams: New York State Department of Environmental Conservation.

Bogan, A.E., 1993, Freshwater bivalve extinctions (Mollusca: Unionidae): a search for causes: American Zoologist, v. 33, p. 599-609.

Borchard, D., Legendre, P., and Drapeau, P., 1992, Partialling out the spatial component of ecological variation: Ecology, v. 73, p. 1045-1055.

Brim-Box, J., and Mossa, J., 1999, Sediment, land use, and freshwater mussels: prospects and problems: Journal of the North American Benthological Society, v. 18, no. 1, p. 99-117.

Butch, G.K., Lumia, R., and Murray, P.M., 1998, Water Resources Data New York -- Water Year 1997 Volume 1. Eastern New York excluding Long Island: U.S. Geological Survey Water-Data Report NY-97-1.

Frissell, C., Liss, W., Warren, C., and Hurley, M., 1986, A hierarchical framework for stream habitat classification - Viewing streams in a watershed context:

Environmental Management, v. 10, p. 199-214.

Jongman, R.H., ter Braaak, C.J.F., and van Tongeren, O.F.R., 1987, Data analysis in community and landscape ecology: Wageningen, the Netherlands, Pudoc, 299 p.

Krejmas, B.E., Harkness, W.E., Carswell, W.J., Jr., and Darling, H.L., 1998, Report of The River Master of the Delaware River For the Period December 1, 1997 November 30, 1998: U.S. Geological Survey OpenFile Report 00-431, 93 p.

Lawrence, G.B., David, M.B., Lovett, G.M., Murdoch, P.S., Burns, D.A., Stoddard, J.L., Baldigo, B.P., Porter, J.H., and Thompson, A.W., 1999, Soil calcium status and the response of stream chemistry to changing acid deposition rates: Ecological Applications, v. 9, no. 3, p. 1059-1072.

Lawrence, G.B., David, M.B., Shortle, W.C., Bailey, S.W., and Lovett, G.M., 1998, Evidence of soil-base depletion by acid deposition in the northeastern U.S., in Sugar Maple Ecology and Health, Warren, PA, U.S. Forest Service.

Lawrence, G.B., Lincoln, T., Horan-Ross, D., Olson, M., and Waldron, L., 1995, Analytical Methods of the U.S. Geological Survey's New York District Water-Analysis Laboratory: U.S. Geological Survey Open-File Report 95-416, $78 \mathrm{p}$.

Layzer, J.B., and Madison, L.M., 1995, Microhabitat use by freshwater mussels and recommendations for determining their instream flow needs: Regulated Rivers: Research \& Management, v. 10, p. 329-345. 
Legendre, P., and Legendre, L., 1998, Numerical ecology, Second English edition (Second English ed.): Oxford, Elsevier.

Master, L.L., 1990, The imperiled status of North American aquatic animals: Biodiversity Network News, v. 3, no. 3, p. 1-8.

Meador, M., Hupp, C., Cuffney, T., and Gurtz, M., 1993, Methods for Characterizing Stream Habitat as Part of the National Water-Quality Assessment Program: U.S. Geological Survey 93-408.

Metcalfe-Smith, J.L., Di Maio, J., Stanton, S.K., and Mackie, G.L., 2000, Effect of sampling effort on the efficiency of the timed search methods for sampling freshwater mussel communities: Journal of the North American Benthological Society, v. 19, no. 4, p. 725-732.

Michaelson, D.L., and Neves, R.J., 1995, Life history and habitat of the endangered dwarf wedgemussel Alasmidonta heterodon (Bivalvia: Unionidae): Journal of the North American Benthological Society, v. 14, no. 2 , p. 324-340.

Murdoch, P.S., and Stoddard, J.L., 1992, The Role of Nitrate in the Acidification of Streams in the Catskill Mountains of New-York: Water Resources Research, v. 28 , no. 10 , p. $2707-2720$.

Nature Conservancy, 1995, Neversink River Bioreserve Strategic Plan: The Nature Conservancy Lower Hudson Chapter.

Nature Conservancy, 1999, Neversink River Site Conservation Plan: Vision, Target and Stategy Update for 1999-2002: The Nature Conservancy Lower Hudson Chapter.

Platts, W., Megahan, W., and Minshall, G., 1983, Methods for evaluating stream, riparian, and biotic conditions: U.S. Forest Service INT-138.

Poff, N.L., Allan, J.D., Bain, M.B., Karr, J.R., Prestegaard, K.L., Richter, B.D., Sparks, R.E., and Stromberg, J.C., 1997, The natural flow regime: a paradigm for river conservation and restoration: Bioscience, v. 47 , no. 11 , p. 769-784.

Rantz, S.E., 1983, Measurement and computation of streamflow--v. 1, Measurement of stage and discharge: U. S. Geological Survey 2175.

Richter, B.D., Baumgartner, J.V., Braun, D.P., and Powell, J., 1996, A method for assessing hydrologic alteration within ecosystems: Conservation Biology, v. 10, p. 1163-1174.

Richter, B.D., Baumgartner, J.V., Wigington, R., and Braun, D.P., 1997b, How much water does a river need?:

Freshwater Biology, v. 37, p. 231-249.

Richter, B.D., Baumgartner, J.V., Braun, D.P., and Powell, J., 1998, A spatial assessment of hydrologic alteration within a river network: Regulated Rivers Research and Management, v. 14, p. 329-340.
Richter, B.D., Braun, D.P., Mendelson, M.A., and Master, L.L., 1997a, Threats to imperiled freshwater fauna: Conservation Biology, v. 11, no. 5, p. 1081-1093.

Simonson, T.D., Lyons, J., and Kanehl, P.D., 1993, Guidelines for evaluating fish habitat in Wisconsin streams: U. S. Forest Service NC-164.

-1994, Quantifying fish habitat in streams: transect spacing, sample size, and a proposed framework: North American Journal of Fisheries Management, v. 14, p. 607-615.

Strayer, D.L., 1983, The effects of surface geology and stream size on freshwater mussel (Bivalvia: Unionidea) distributions in southeastern Michigan, U.S.A: Freshwater Biology, v. 13, p. 253-264.

Strayer, D.L., 1993, Macrohabitats of freshwater mussels (Bivalvia: Unionacea) in streams of the northern Atlantic Slope: Journal of the North American Benthological Society, v. 12, no. 3, p. 236-246.

Strayer, D.L., 1999, Use of flow refuges by unionid mussels in rivers: Journal of the North American Benthological Society, v. 18 , no. 4 , p. 468-476.

Strayer, D.L., Hunter, D.C., Smith, L.C., and Borg, C.K., 1994, Distribution, abundance, and roles of freshwater clams (Bivalvia, Unionidae) in the freshwater tidal Hudson River: Freshwater Biology, v. 31, p. 239-248.

Strayer, D.L., and Jirka, K.J., 1997, The pearly mussels of New York State: Albany, NY, The University of the State of New York, $113 \mathrm{p}$.

Strayer, D.L., and Ralley, J., 1991, The freshwater mussels (Bivalvia: Unionidea) of the upper Delaware River drainage: American Malacological Bulletin, v. 9, no. 1, p. 21-25.

-1993, Microhabitat use by an assemblage of streamdwelling unionaceans (Bivalvia), including two rare species of Alasmidonta: Journal of the North American Benthological Society, v. 12, no. 3, p. 247 258.

Strayer, D.L., Sprague, S.J., and Claypool, S., 1996, A range-wide assessment of populations of Alasmidonta heterodon, an endangered freshwater mussel (Bivalvia: Unionidae): Journal of the North American Benthological Society, v. 15, no. 3, p. 308-317.

ter Braak, C.J.F., and Smilauer, P., 1998, CANOCO Reference manual and users guide to Canoco for Windows, Software for canonical community ordination (version 4): Ithaca, NY, Microcomputer Power, 352 p.

Vannote, R.L., and Minshall, G.W., 1982, Fluvial processes and local lithology controlling abundance, structure, and composition of mussel beds: Proceedings of the National Academy of Sciences, v. 79, p. 4103-4107.

Vaughn, C.C., and Taylor, C.M., 1999, Impoundments and the decline of freshwater mussels: A case study of an 
extinction gradient: Conservation Biology, v. 13, no. 4, p. $912-920$.

-2000, Macroecology of a host-parasite relationship: ECOGRAPHY, v. 23, p. 11-20.

Williams, J.D., and Neves, R.J., 1995, Freshwater mussels: a neglected and declining aquatic resource, in LaRoe, E.T., Farris, G.S., Puckett, C.E., Doran, P.D., and Mac, M.J., eds., Our living resources: a report to the nation on the abundance, and health of U.S. plants, animals, and ecosystems: Washington, D.C., U.S. Department of Interior, National Biological Service, p. 19-21.

Williams, J.D., Warren Jr., M.L., Cummings, K.S., Harris, J.L., and Neves, R.J., 1993, Conservation status of freshwater mussels of the United States and Canada: Fisheries, v. 18, p. 6-22.

Wolman, M., 1954, A method for sampling coarse river-bed material: Transactions of the American Geophysical Union, v. 235, p. 951-956. 